\title{
Waxing and Waning: Periods of Intermittency in Criminal Careers
}

\section{Vere van Koppen ${ }^{1} \cdot$ Elanie Rodermond $^{1} \cdot$ Arjan Blokland $^{2,3}$}

Received: 9 October 2018 / Revised: 13 December 2019 / Accepted: 18 December 2019 / Published online: 7 March 2020

(C) The Author(s) 2020

\section{Abstract}

Objectives Focusing on intermittency as a specific criminal career dimension, the present study explores the distribution of intermittency as it occurs across individuals and in the course of the criminal career.

Methods Using conviction data on repeat offenders $(N=3716)$ from the Criminal Career and Life-Course Study (CCLS), overall patterns of intermittency (measured as conviction-free intervals between subsequent convictions) are analyzed. Given different levels of offending before and after conviction-free periods, we examine the length of the conviction-free interval and the extent to which offending in terms of frequency and specialization changes after a conviction-free period.

Results On average, repeat offenders show relatively short intermittency periods. However, conviction-free intervals tend to increase towards the end of the criminal career regardless of offending frequency. A substantial minority of offenders has a criminal career characterized by more than one spell of frequent offending separated by an extended period of non-offending. As the intermittency period increases, offending specialization across offending periods declines, but not for all types of offenses.

Conclusions This study shows that even after committing several offenses, some offenders experience a prolonged conviction-free interval only to resume offending at a non-trivial rate. Due to the length of their conviction-free interval, these offenders would erroneously have been labeled desisters in many prior studies.

Keywords Intermittency $\cdot$ Crime-free periods $\cdot$ Criminal careers

Vere van Koppen

mv.van.koppen@vu.nl

Extended author information available on the last page of the article 


\section{Introduction}

Within the criminal career paradigm, the criminal career is defined as the longitudinal sequence of crimes committed by an individual offender [7]. Defined as such, the criminal career is argued to display several related, yet distinct dimensions, like onset, frequency, and duration. Different amalgamations of these dimensions are taken to reflect different constellations of the personal and contextual factors that combine into an individual's criminal inclination as it develops over his or her life-course. Offending that is late onset, minor, and temporary, for example, is taken to signal weak criminal propensity, whereas offending that is early onset, highly frequent, and persistent is thought to indicate a strong(er) and less malleable criminal inclination [32]. Given its theoretical and practical relevance, much recent research has focused on distinguishing desistance from persistence or desisters from persisters (e.g. [26]). Upon closer examination, however, researchers have found that making this distinction is a lot harder than it looks at first glance.

If persistence is defined as the continuation of offending than constituting its mirror image, desistance refers to the discontinuation of offending. However, at least two problems in defining desistance in this way arise. The first is a methodological one. If desistance is operationalized as the termination of offending or transferring from a state of offending to a state of non-offending, at what point can one safely conclude that an offender has desisted? In essence, any study that does not cover offenders' entire lifespan increases the likelihood of false positives - that is, incorrectly labeling former offenders as desisters, who would, given an extended follow-up period, have eventually committed another crime $[12,15]$. The second problem is of a conceptual nature and has to do with equaling desistance with termination. If the criminal career is taken to reflect the materialization of the individual's underlying criminal inclination, then overnight change as implicated by termination seems unlikely. Conceptually, the discontinuation of offending is arguably better imagined as the end point of a more gradual desistance process that starts and continues well before criminal propensity finally drops below some critical threshold and offending stops [8, 23]. One of the telltale signs of desistance, noticeable prior to full termination, may therefore be increasing time gaps between subsequent offenses or increased intermittency [41].

Another reason to examine intermittency, rather than termination, is mentioned by Maruna [27] when he states that, over the course of the criminal career, "termination takes place all of the time." Even the most prolific offenders are likely to experience periods - days, weeks, or even months - of non-offending [28]. Especially when criminal careers are studied based on official data, periods of non-offending conflate the absence of criminal behavior with the absence of getting caught, resulting in even sparser offending patterns. Even in the absence of permanent termination, the question becomes at what point - if any-intermittency in offending can be taken to signal changes - either temporary or lasting - in criminal inclination, rather than the probabilistic process of arrest and conviction. Finally, to the extent that prolonged periods of intermittency signal substantial, be it temporal, changes in criminal inclination, one could argue that, instead of a single, yet highly intermittent criminal career, some offenders are better thought of as embarking on a second criminal career following a longer term hiatus in offending [2] — one that might well be qualitatively different from the first stint of offending in terms of frequency, seriousness, and/or crime mix. 
While a number of previous studies have begun to address some of these questions, overall, the empirical and theoretical attention for intermittency is still scant. In part, this is due to the data requirements that follow from the above considerations. To adequately address intermittency and avoid the methodological problems that have plagued prior research, longitudinal data is needed spanning the entire, or at least the larger part of, individuals' criminally active period. As up front, the total period - or periods - of criminal activity is unknown, studies on intermittency should ideally cover the early teens until old age or death for each offender in the sample.

The present study uses data from the Criminal Career and Life-Course Study (CCLS) to describe patterns of intermittency in a sample of repeat offenders $(N=$ 3716) taken from a larger study of individuals that were tried for a criminal offense in the Netherlands in 1977 and followed up to 2005 [3]. It will examine the extent to which offense patterns - in terms of frequency, seriousness, and specializationchange after different periods of non-offending. Using the CCLS data set enables us to examine offending patterns for a period of over 40 years, coming close to covering the entirety of the criminologically relevant life span and allowing us to examine intermittency in offenders who, in studies with more limited follow-up periods, would falsely have been labeled "desisters."

\section{Intermittency in Offending}

Conceptually, scholars have argued that it is important to distinguish desistance, the process of transferring from a state of offending to a state of non-offending, from termination, the maintenance of a state of non-offending [23]. As with overcoming addictive behaviors, offenders may repeatedly engage in the desistance process over the course of their criminal career, but relapse to offending before reaching its endpoint of termination. Whereas desistance may reflect the offenders' willingness to change, termination (or secondary desistance) may very well require an internal transformation in the way the offender perceives himself and his place in the world [27]. The process of desistance may involve changes in several criminal career parameters, including reduced frequency, seriousness, and versatility of offending [25]. As offenders progress through the desistance process, periods of intermittency or the time gaps between subsequent offenses are also likely to increase [41]. Many empirical studies, however, have simply defined desistance as the absence of (registered) offending for some designated period, depending on the follow-up of the study (see [20] for a review). Given that desistance is likely accompanied by increasing intermittency, studies with a limited time frame will probably label some offenders desisters while they did not reach actual termination (even though they might be in the process of desistance).

This becomes problematic especially if relapse is common among this group and factors implicated in criminal career termination may differ from those predicting intermittency. Previously, Kurlychek et al. [21] found that the risk of a police contact among a population of prior offenders, whom they followed from age 18 to age 25-26, rapidly decreased with the years passing by since the last police contact. They concluded that "after some period of time has passed, the risk of a new criminal event among a population of nonoffenders and a population of prior offenders becomes similar" (p. 499). In a more recent study, Bushway et al. [9] found that, conditional on age and the frequency and seriousness of prior offending, former offenders' risk of 
relapse (in the form of a new conviction) is not significantly different to that of the general population only after 10 years of remaining crime-free. These insights can be taken to provide some guidance in terms of the length of the follow-up needed to begin to distinguish desistance from termination (e.g. [6, 9]).

Criminologists have also questioned whether one can desist from an incidental offense or whether a more substantial pattern of offending is required [23]. Formally speaking, committing a single crime already constitutes a criminal career, be it one with a minimum frequency, versatility, and duration. Such a formalistic stance, however, renders much of the parameters defining the process of desistance meaningless- e.g. frequency and versatility cannot go down after just committing one offense-and several scholars have therefore argued that desistance is only relevant among those showing some substantive amount of crime; "substantive" usually defined by some arbitrary minimum number of offenses (e.g. [4]). Conceptually, only changes in behavior that reflect changes in the individuals underlying propensity for that behavior will inform us on the causal processes involved in that change. As the frequency of offending goes up, the more unusual and therefore the more relevant a period of nonoffending is in this respect.

A final question with regard to intermittency was raised by Barnett et al. [2]. Finding some offenders to reengage in offending after unanticipatedly extended conviction-free intervals, these researchers asked whether after such a substantial period of abstinence it would be better to speak of offenders embarking on a second criminal career rather than interpreting their re-offending as the continuation of their initial criminal career. In line with the notion of two separate criminal careers, is research showing adolescent crime to be differently motivated than adult offending [13], and studies that find circumstances that promote desistance among young adults may rather offer opportunities for offending in the later adult years [43]. As with desistance becoming a more meaningful term when the number of previously committed crimes increases, intermittency may likewise acquire different theoretical significance for the criminal career paradigm as the length of the crime-free interval increases.

\section{Prior Research}

Though still to a limited extent compared with desistance and persistence, intermittency in offending has been addressed both quantitatively and qualitatively in prior research [38]. What is meant by "intermittency" in these studies, however, differs in important ways. Firstly, the term intermittency has been used as a label to characterize offenders. Examining the criminal careers of 49 habitual felons, Petersilia et al. [37] distinguished intensive offenders from intermittent offenders. Whereas the former showed goal-directed criminal activity and considered themselves professional criminals, the criminal behavior of the latter was more opportunistic and less profitable. Intermittent offenders also did not think of themselves as professional criminals. Such a qualitative operationalization is reminiscent of Matza [28] describing how many delinquents are "casually, intermittently, and transiently immersed in a pattern of illegal action," drifting in limbo between the legal and the illegal without committing to either one. Intermittency used in this way seems to primarily reflect the offender's state of mind rather than some quantifiable criminal career dimension. Petersilia et al. [37], for instance, find that the adult crime rate exceeded one crime per street month for $94 \%$ of intensive offenders, compared with $21 \%$ of intermittent offenders. While 
these researchers find intermittency and the frequency of offending to be clearly related, intermittency is not logically defined by offending frequency per se. Similarly, in their qualitative follow-up study of formerly delinquent boys, Laub and Sampson [24] identified a group of intermittent offenders, zigzagging in and out of crime. Many of these men reported a history of severe alcohol abuse that could account for their erratic offending patterns.

Other researchers refer to intermittency as the gap between two consecutive offenses within a single offender's criminal career [38]. Whereas unlike breathing, in which inhaling is directly followed by exhaling, offending is not a perpetual behavior; in theory, this definition results in all offenders showing some level of intermittency, be it in terms of weeks, days, hours, or even minutes. In practice, however, empirical work applying this definition typically uses a more coarse-meshed time scale-e.g. months - hence confining the minimal interval between offenses still counted as intermittent. Analyzing police data from the Philadelphia Birth Cohort Study up to age 26 and operationalizing intermittency as the number of months between police contacts, Metcalfe and Baker [30] and Baker et al. [1] found an average intermittency gap of 14 months. Moreover, intermittency was shown to be associated with both sex and age, with girls showing longer periods of intermittency and intermittency periods increasing as offenders grew older. Early starting chronic offenders - those committing five or more offenses - showed the shortest intermittency periods. Chronic offenders with shorter gaps between police contacts also evidenced more serious offending. Similarly, Hodge [18], using the Pathways to Desistance data, defined the minimum period of intermittency as a community month with no self-reported crime event hemmed between months with at least one crime event. She found that over the 87month course of the observation period, recidivating offenders reported an average of nearly five periods of intermittency that together accounted for two thirds of their community time during the study's follow-up. Metcalfe et al. [31], also using the Pathways to Desistance dataset, adopted the theoretical framework of Sampson and Laub $[24,42]$ to study intermittency in offending. These authors used what they called a wave-based measure of intermittency - the average number of months between each offense in that particular wave - enabling them to assess the influence of bonds during a specific wave on gaps in arrests during the same wave. They found that employment is consistently related to intermittency and that marriage duration and more time spent in school were associated with longer gaps between arrests. Finally, Ouellet [35] studied intermittency among a sample of 172 Canadian inmates, defining intermittency as months without self-reported lucrative criminal activity. However, rather than on periods of intermittency themselves, this study focused on predicting the onset and termination of the intermittent period.

Still, others reserve the term intermittency only for "unpredicted" gaps in offending. That is, these researchers chose to speak only of intermittency when the crime-free period between offenses exceeds what could be expected based on the offender's underlying criminal inclination and the probability with which this inclination materializes in the actual commission of an offense. Studying offenders in the Cambridge Study in Delinquent Development, Barnett et al. [2] discovered five men who frequently offended during their adolescence and young adult years (5.8 offenses on average between ages 16.4-19.4), yet subsequently remained conviction-free for a period of 7 to 10 years, only to get reconvicted at age 27.4 on average. The duration of the crime free period these men experienced far 
exceeded what was anticipated based on their prior criminal behavior. Three of these five intermittent offenders were convicted for a second time after their prolonged conviction-free interval, which could signal that these men were on the brink of starting a second criminal career. These findings led the researchers to conclude that "the indication that a small number of offenders may have ended one criminal career and then restarted another after a hiatus suggests a direction in which criminal career models may be usefully extended in the future" ([2]:384). In response, Nagin and Land $[22,33]$ incorporated an "intermittency parameter" $\pi$ in their statistical model of the criminal career, with $\pi=1$ indicating the offender is always active. This intermittency parameter turned out to be strongly associated with age-peaking at age 20-to be higher in the year directly following a conviction and to be positively associated with an index of time stable characteristics known to influence the frequency of offending-e.g. low intelligence, high daring, and having a criminal parent-indicating that frequent offenders were also likely to be active offenders in any given year. As anticipated by Barnett et al. [2], models including this intermittency parameter provided a better fit to the offending data than those without.

Finally, qualitative research into intermittency separates conscious breaks from unintentional breaks in offending, without reference to the length of the break, and only the former denoting intermittency [11]. Using qualitative data from the Stockholm Life Course Project, Carlsson [10] distinguished two forms or phases of intermittency as described by offenders interviewed in this study. The first form was that of a temporary hold up of offending. Offenders described an occasional desire for a timeout from offending, which, in turn, materialized during a period of non-offending, yet without any real intention of wanting to terminate their criminal behavior. Offenders described themselves as "still in the game" despite their temporal abstinence and were usually quick to resume their criminal lifestyle; hold up periods lasted only weeks, months, or - exceptionally - a year ([10]:924). The second form, or narrative, used to explain that periods of intermittency is that of attempted change. This form is different from the first in that offenders voiced their desire to change their criminal ways, which brought about a period of non-offending. After going straight for some time, these offenders finally paid to the temptations of their former criminal lifestyle and relapsed into offending. Though periods of intermittency resulting from attempts to quit were usually longer than those resulting from "holding up," they were still often described as only "a year or two" ([10]:924). More recently, DeShay and Vieriatis [11] studied intermittency among 16 ex-prisoners. Like Carlsson [10], their findings indicated that some offenders consciously take breaks from offending, knowing they will return to offending in the (near) future. In other occasions, intermittency is better framed as failed attempts at desistance. The men interviewed by DeShay and Vieriatis [11] mentioned pressure by their spouses and lack of support from family and friends as important drivers of their return to crime.

\section{Prior Limitations and Current Study}

Most prior studies quantitatively studying intermittency have used data covering offenders' criminal careers only up to their late twenties or early thirties. Due to this limited follow-up period, intermittency as measured in these studies is likely 
to disproportionately reflect periods of "holding up" offending, rather than attempts to quit a criminal lifestyle, especially since the former are found to be most prevalent among younger offenders ([10]: 924). These studies are consequently limited in informing the distinction between intermittency and termination as the maximum period of intermittency is restricted by the duration of the follow-up period. As a result, most prior studies do not elaborate on the type of intermittency found in the Cambridge study, the kind that sparked the question to what extent offenders can be said to embark on two-or perhaps even more-criminal careers during one life time [2]. Finally, with this question in mind, one could argue that just like desistance may require some minimum number of offenses to be relevant, intermittency also requires some minimum amount of offenses both prior and after the intermittent period to be worthy of study. Even in the Cambridge study, only three out of five highly intermittent offenders committed a second offense after their intermittent period ([2]:384). If, for instance, re-offending after intermittency remains limited to only one or two offenses, and there seems little ground to speak of a second criminal "career."

Through its use of conviction data covering offenders' criminal careers from the earliest possible age all the way into the later adult years, the present study is able to address the distribution of intermittency periods across the entire criminal career, and allow for intermittency periods that exceed the months or even years of intermittency found in previous research. Defining intermittency as the time period between two convictions in one's criminal career and building on results from prior studies, intermittency is taken as a proxy for the individual's underlying criminal inclination; those low in criminal inclination are predicted to show longer periods of intermittency on average than those high in criminal inclination [1]. Periods of intermittency are likely to narrow during times of offending escalation, whereas gaps between subsequent offenses are expected to increase when individuals are in the process of desistance [25, 41]. In the second part of the current analysis, intermittency is narrowed down to denote the longest crime-free period in the offender's criminal career in an attempt to address the question raised by prior studies whether highly intermittent offenders are best viewed as engaging in multiple criminal careers [2]. Specialization in offending - or more specifically, the tendency to re-offend with the same type of offense-across the longest gap between convictions is taken to evidence continuity of a single criminal career, whereas diversity — or the tendency to re-offend with a different type of offense across the longest gap between convictions - is taken to evidence the start of a second criminal career. To the extent that the notion of multiple criminal careers has merit, specialization from one criminal period into the next one is expected to decrease with increased periods between subsequent offenses. In other words, specialization is expected to decrease when the long gap observed between offenses was least anticipated.

In sum, this leads to the following hypotheses to be tested in the current study:

1. Periods of intermittency are longest when both the number of offenses preceding the intermittent period and the number of offenses following that period are low, as this is taken to signal an overall low criminal inclination.

2. Periods of intermittency are shorter (than under 1.) when the number of offenses preceding the intermittent period is low, but the number of offenses following that 
period is high, as acceleration in the criminal career is taken to signal increasing criminal inclination.

3. Periods of intermittency are shorter (than under 1.) when the number of offenses preceding the intermittent period is high, but the number of offenses following that period is low, as de-acceleration in the criminal career is taken to signal desistance and decreasing criminal inclination.

4. Periods of intermittency are shortest (compared with 1.-3.) when the number of offenses preceding the intermittent period is high and the number of offenses following that period is high, as this is taken to signal an overall high criminal inclination.

5. As periods of intermittency increase, offenders are increasingly less likely to reoffend with a similar type of offense.

\section{Data and Methods}

\section{Sample}

The current study uses data from the Criminal Career and Life-Course Study (CCLS). The CCLS is based on a representative sample of $4 \%$ of all criminal offenses tried in the Netherlands in 1977. ${ }^{1}$ The original sample consists of 5164 individuals and follows individuals from age 12 to their age in 2005 or death (for more detailed information on the dataset, see Blokland [3] and Blokland et al. [5]). In the current study, intermittency refers to the gap that occurs between subsequent offenses $[1,18,38]$ and is determined on an annual term. For that reason, we exclude individuals who either committed just one crime or who committed multiple crimes but only during one single age year. The remaining 3716 individuals ( $72 \%$ of the original CCLS sample) are included in this study. Most of them (94\%) are male (see Table 1). In 1977, their mean age was 27, ranging from 12 to 65 . By the end of 2005, the oldest individual still alive was 93 years old.

\section{Offending Careers}

The entire criminal careers of the 3716 repeat offenders in the current sample were reconstructed using abstracts from the General Documentation Files of the Criminal Record Office. These abstracts contain information on the timing and nature of offenses for which offenders came into contact with the criminal justice system. They also contain information on how the criminal case was adjudicated and, when applicable, the severity of the sentence imposed. As for the purpose of scientific research, these abstracts are not subjected to periods of limitation, we were able to reconstruct sample members' criminal careers starting from age 12-which is the minimum age of legal responsibility in the Netherlands - all the way up to their age in 2005, or the moment of their death if this occurred prior to that. While the abstracts hold information on all criminal cases brought to the attention of the public prosecutor, here we only take into

\footnotetext{
${ }^{1}$ Because the number of some types of offenses in the sample was disproportionally high and more serious offenses were underrepresented in the sample, some common types of offenses were under sampled and some less common (mainly serious) offenses were over sampled.
} 
Table 1 Descriptive statistics ( $N=3716$, only those with multiple criminally active years)

\begin{tabular}{llll}
\hline & M & SD & Range \\
\hline Gender (1 = male) & 0.94 & 0.24 & $0-1$ \\
Age in 1977 (index year) & 27.2 & 10.1 & $12-65$ \\
Age in 2005 (end data collection) & 55.2 & 10.1 & $40-93$ \\
Age first conviction & 20.6 & 7.1 & $12-60$ \\
Age last conviction in dataset & 42.9 & 11.3 & $15-78$ \\
Career length (years from first to last conviction) & 22.3 & 11.2 & $1-64$ \\
Total number of years with at least one conviction & 8.4 & 6.6 & $2-46$ \\
Total number of convictions in career & 16.6 & 21.9 & $2-318$ \\
Total number of years in prison & 1.8 & 4.0 & $0-32.4$ \\
Mean intermittency spell per individual & 2.9 & 2.8 & $0-19.5$ \\
Maximum intermittency spell per individual & 8.4 & 6.3 & $0-40$ \\
\hline
\end{tabular}

account those cases that ended in a guilty verdict, prosecutorial fine, or a prosecutorial waiver due to policy reasons. Cases ending in an acquittal or waivered because of lack of evidence were thus excluded. Abstracts from the General Documentation Files also provide information on the type and severity of the sentence imposed, i.e. the length of the custodial sentence.

\section{Measures of Intermittency}

To determine intermittency on an annual term, the offenders' age is used as the basis. For each age year, it is determined whether the offender was criminally active (was convicted for one or multiple crimes) (1) or was not (0). As long as individuals are not reconvicted, intermittency increases every year. If an individual is convicted again after a period of being conviction-free, intermittency is set to zero. ${ }^{2}$ Periods during which individuals are serving a custodial sentence are not included when calculating the length of the intermittent period. For example, when the time between two subsequent convictions is 2 years, but the offender is imprisoned for 6 months following the first convictions, the intermittency period is said to be 1.5 years. ${ }^{3}$ In sum, for each age year, the number of years since the last criminally active year is determined, subtracted by the number of years spent in prison since the last criminally active year. Since this study uses official data, it is likely that not all of offenders' criminal

\footnotetext{
${ }^{2}$ Since we have information on offending on an annual term, we defined intermittency as the number of years since the last criminally active year. Intermittency has a value of ' 0 ' in the case individuals are criminally active in directly subsequent years.

${ }^{3}$ Note that information on the length of imprisonment was taken from conviction records, as such we are unable to control for any periods of pre-trial remand. Upon sentencing, any period spent in pre-trail demand is considered as prison time already served, advancing the offenders' actual release. We were however able to control for early release, as this was applied following a standard protocol for all offenders during almost the entire period of our study. If anything then, by subtracting the total length of imposed imprisonment from the period between offenses, we underestimate the actual length of intermittency.
} 


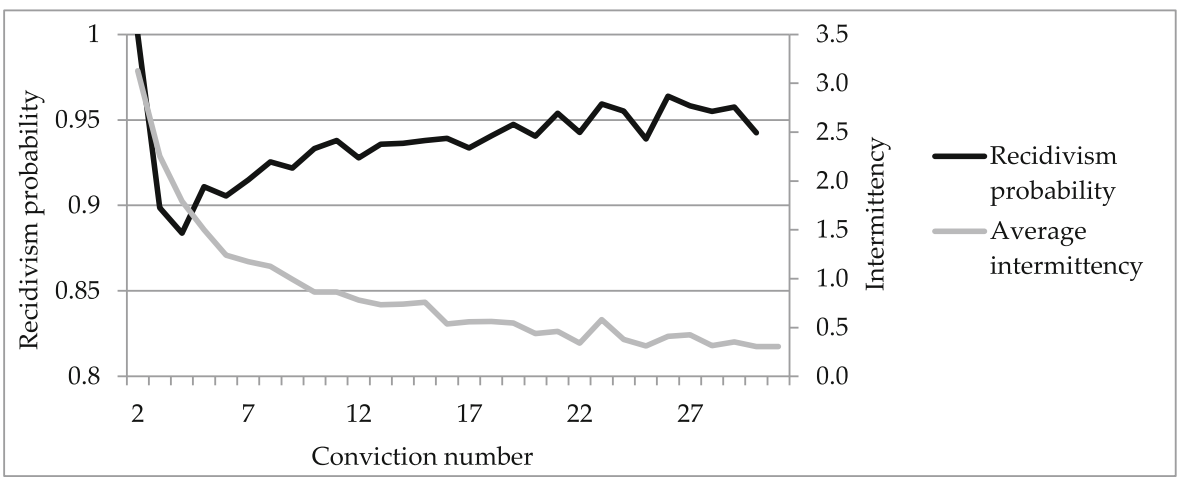

Fig. 1 Recidivism probability and average interval between subsequent convictions (intermittency) by conviction number

activity is captured. As a result, the length of intermittency periods might be overestimated. Would we have complete (self-reported) information on actual criminal behavior, intermittency spells would likely be shorter.

\section{Results}

\section{Offending Careers and Intermittency}

The 3716 repeat offenders included in this study had an average of 17 convictions during their total criminal career, with one offender convicted 318 times topping the list (Table 1). On average, these repeat offenders experienced their first conviction at age 21 and have criminal careers spanning more than 20 years. The mean spell between two criminal years equals 2.9 years. The maximum intermittency spell —or the longest period without convictions - in an individual's criminal career is 8.4 years on average.

The solid black line in Fig. 1 depicts the likelihood of recidivism after a given number of convictions. As with a growing number of convictions, the share of chronic offenders among those at risk to recidivate increases; the slope of this curve levels off with an increasing number of previous convictions (see also: [40]). The solid gray line in Fig. 1 shows the average period of intermittency between each conviction and the next. In line with the notion that shorter intermittency spells signal higher criminal inclination, the average period between subsequent convictions decreases as the number of previous convictions increases.

This line of thought is further substantiated by Fig. 2, which depicts the average intermittency spell between subsequent convictions for offenders who differ in the total number of convictions in their entire criminal careers. The higher the total number of convictions over the entire criminal career, the shorter the average intermittency spell. ${ }^{4}$ For each offender group distinguished in Fig. 2, the average intermittency period increases as the number of convictions approaches the observed maximum for that particular group. This is in line with the notion that the desistance process is

\footnotetext{
${ }^{4}$ Note that this should not necessarily be the case as it could also be that regardless of the ultimate total number of convictions offenders show similar intermittency patterns during the start of their criminal career.
} 


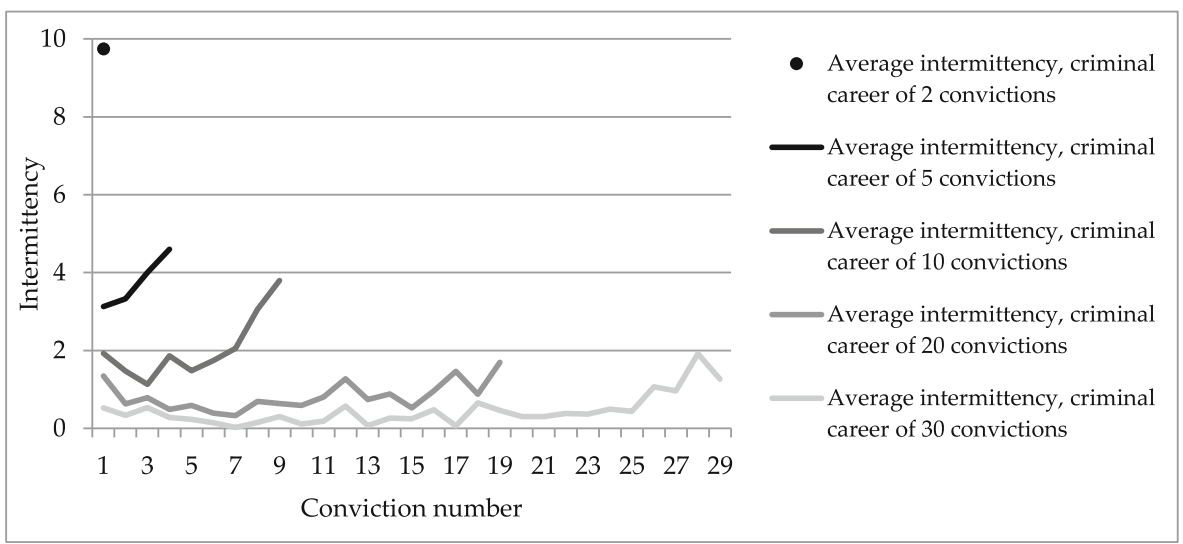

Fig. 2 Average interval between subsequent convictions (intermittency) by conviction number, by total number of convictions in the criminal career

characterized by convictions becoming more widely spaced prior to the point of termination. As this development is present in all offender groups, increased intermittency seems to signal desistance regardless of the extent of the previous criminal career.

Just as desistance has been argued to be a relevant concept only for those committing at least a certain minimum of offenses [23], so can intermittency be said to be relevant only for those who commit a certain amount of offenses both prior as well as after the intermittent period. Table 2 therefore displays the average longest intermittency spell across offenders' criminal careers showing different combinations of the number of pre- and post-intermittency convictions. The cells in this cross tabulation

Table 2 Average longest intermittency spell in the criminal career, by number of pre and post convictions

\begin{tabular}{|c|c|c|c|c|c|c|c|c|c|c|c|c|c|c|c|c|c|c|c|c|c|c|c|}
\hline & \multicolumn{22}{|c|}{ Number of post convictions } \\
\hline & & 1 & 2 & 3 & 4 & 5 & 6 & 7 & 8 & 9 & & 10 & 11 & 12 & 13 & 14 & 15 & 16 & 17 & 18 & 19 & 20 & $>20$ \\
\hline & & \multicolumn{22}{|c|}{ Average longest spell in career in years $(N)$} \\
\hline \multirow{21}{*}{$\begin{array}{l}\text { Number } \\
\text { of pre } \\
\text { convictions }\end{array}$} & 1 & $\begin{array}{l}9.8 \\
(377)\end{array}$ & $\begin{array}{l}11.0 \\
(171)\end{array}$ & $\begin{array}{l}10.3 \\
(60)\end{array}$ & \begin{tabular}{|l|}
10.3 \\
$(51)$
\end{tabular} & $\begin{array}{l}13.5 \\
(33)\end{array}$ & $\begin{array}{l}8.7 \\
\text { (18) }\end{array}$ & $\begin{array}{l}7.9 \\
(16\end{array}$ & $\begin{array}{l}11 \\
\text { (1 }\end{array}$ & & & $\begin{array}{l}8.6 \\
(10)\end{array}$ & $\begin{array}{l}8.1 \\
(7)\end{array}$ & \begin{tabular}{|l}
10.3 \\
$(7)$
\end{tabular} & $\begin{array}{l}8.6 \\
(5)\end{array}$ & $\begin{array}{l}5.6 \\
(5)\end{array}$ & $\begin{array}{l}6.2 \\
(5)\end{array}$ & $\begin{array}{l}9.3 \\
(6)\end{array}$ & \begin{tabular}{|l|}
9 \\
$(2)$
\end{tabular} & $\begin{array}{l}8.5 \\
\text { (4) }\end{array}$ & $\begin{array}{l}8 \\
\text { (2) }\end{array}$ & $\begin{array}{l}6.8 \\
(5)\end{array}$ & $\begin{array}{l}4.9 \\
(52)\end{array}$ \\
\hline & 2 & $\begin{array}{l}11.2 \\
(217)\end{array}$ & $\begin{array}{l}9.2 \\
(79)\end{array}$ & $\begin{array}{l}9.2 \\
(55)\end{array}$ & $\begin{array}{l}10,4 \\
(35)\end{array}$ & $\begin{array}{l}7.8 \\
(20)\end{array}$ & $\begin{array}{l}12.1 \\
(10)\end{array}$ & $\begin{array}{l}18 \\
\text { (3) }\end{array}$ & $\begin{array}{l}9 . \\
16\end{array}$ & & $\begin{array}{l}\overline{.0} \\
0)\end{array}$ & $\begin{array}{l}5.8 \\
(8)\end{array}$ & $\begin{array}{l}4.8 \\
(4)\end{array}$ & \begin{tabular}{|l|}
6.6 \\
$(5)$
\end{tabular} & \begin{tabular}{|l}
5.0 \\
(1)
\end{tabular} & \begin{tabular}{|l|}
8.0 \\
$(6)$
\end{tabular} & \begin{tabular}{|l|}
5.3 \\
$(3)$ \\
\end{tabular} & $\begin{array}{l}6.0 \\
(5)\end{array}$ & $\begin{array}{l}3.7 \\
(3)\end{array}$ & $\begin{array}{l}5.0 \\
(2)\end{array}$ & $\begin{array}{l}5.0 \\
\text { (3) }\end{array}$ & - & $\begin{array}{l}4.3 \\
(18)\end{array}$ \\
\hline & 3 & $\begin{array}{l}10.7 \\
(124)\end{array}$ & $\begin{array}{l}9.7 \\
(67)\end{array}$ & $\begin{array}{l}9.7 \\
(38)\end{array}$ & \begin{tabular}{|l|l}
9.5 \\
$(23)$
\end{tabular} & $\begin{array}{l}10.2 \\
(11)\end{array}$ & $\begin{array}{l}6.3 \\
(8)\end{array}$ & $\begin{array}{l}9.0 \\
(7)\end{array}$ & $\begin{array}{l}11 \\
17\end{array}$ & & & $\begin{array}{l}9.0 \\
(9)\end{array}$ & $\begin{array}{l}6.4 \\
(7)\end{array}$ & \begin{tabular}{|l}
8.6 \\
$(5)$
\end{tabular} & \begin{tabular}{|l}
6.0 \\
$(1)$
\end{tabular} & - & $\begin{array}{l}5.5 \\
\text { (2) }\end{array}$ & $\begin{array}{l}1.0 \\
\text { (1) }\end{array}$ & $\begin{array}{l}5.3 \\
(4)\end{array}$ & - & $\begin{array}{l}4.0 \\
\text { (1) }\end{array}$ & $\begin{array}{l}4.0 \\
\text { (1) }\end{array}$ & $\begin{array}{l}4.2 \\
(16)\end{array}$ \\
\hline & 4 & $\begin{array}{l}11.3 \\
(81)\end{array}$ & $\begin{array}{l}9.9 \\
(43)\end{array}$ & $\begin{array}{l}9.2 \\
(22)\end{array}$ & $\begin{array}{l}8.6 \\
(25)\end{array}$ & $\begin{array}{l}8.0 \\
(7)\end{array}$ & $\begin{array}{l}10.4 \\
(12)\end{array}$ & $\begin{array}{l}7.3 \\
(3)\end{array}$ & $\begin{array}{l}8 . \\
88\end{array}$ & & & $\begin{array}{l}9.3 \\
\text { (3) }\end{array}$ & $\begin{array}{l}10.0 \\
\text { (1) }\end{array}$ & \begin{tabular}{|l}
7.3 \\
$(6)$
\end{tabular} & \begin{tabular}{|l}
6.0 \\
(1)
\end{tabular} & $\begin{array}{l}7.0 \\
\text { (2) }\end{array}$ & $\begin{array}{l}2.5 \\
\text { (2) }\end{array}$ & $\begin{array}{l}.5 \\
\text { (2) }\end{array}$ & - & $\begin{array}{l}4.6 \\
(2)\end{array}$ & $\begin{array}{l}6.0 \\
(2)\end{array}$ & $\begin{array}{l}3.0 \\
\text { (1) }\end{array}$ & $\begin{array}{l}5.3 \\
(10)\end{array}$ \\
\hline & 5 & $\begin{array}{l}9.8 \\
(58) \\
\end{array}$ & $\begin{array}{l}8.5 \\
(29) \\
\end{array}$ & $\begin{array}{l}9.4 \\
(20) \\
\end{array}$ & $\begin{array}{l}9.8 \\
(12 \\
\end{array}$ & $\begin{array}{l}11.2 \\
600 \\
\end{array}$ & $\begin{array}{l}8.1 \\
(7) \\
\end{array}$ & $\begin{array}{l}10 . \\
(8) \\
\end{array}$ & $\begin{array}{r}5 . \\
4 \\
\end{array}$ & & & $\begin{array}{l}8.7 \\
(4) \\
\end{array}$ & $\begin{array}{r}6.7 \\
(4) \\
\end{array}$ & $\begin{array}{l}6.0 \\
\text { (1) }\end{array}$ & \begin{tabular}{|l}
4.7 \\
$(3)$ \\
\end{tabular} & $\begin{array}{l}5.5 \\
(2) \\
\end{array}$ & - & $\begin{array}{l}4.3 \\
\text { (3) } \\
\end{array}$ & - & - & $\begin{array}{l}4.5 \\
\text { (2) } \\
\end{array}$ & - & $\begin{array}{l}4.0 \\
(12) \\
\end{array}$ \\
\hline & 6 & $\begin{array}{l}10.8 \\
(54)\end{array}$ & $\begin{array}{l}7.9 \\
(31)\end{array}$ & $\begin{array}{l}8.9 \\
(20)\end{array}$ & $\begin{array}{l}8.6 \\
\text { (7) }\end{array}$ & $\begin{array}{l}7.0 \\
(10)\end{array}$ & $\begin{array}{l}10.8 \\
(6)\end{array}$ & $\begin{array}{l}5.5 \\
5.5 \\
(5)\end{array}$ & $\begin{array}{l}5 . \\
(5\end{array}$ & & & $\begin{array}{l}5.5 \\
(2)\end{array}$ & $\begin{array}{l}4.7 \\
(2)\end{array}$ & - & $\begin{array}{l}11.5 \\
(2)\end{array}$ & $\begin{array}{l}4.0 \\
\text { (1) }\end{array}$ & - & - & - & $\begin{array}{l}5.5 \\
\text { (2) }\end{array}$ & - & - & $\begin{array}{l}5.5 \\
\text { (4) }\end{array}$ \\
\hline & 7 & $\begin{array}{l}9.5 \\
(48) \\
\end{array}$ & $\begin{array}{l}9.9 \\
(31) \\
\end{array}$ & $\begin{array}{l}9.9 \\
(12) \\
\end{array}$ & $\begin{array}{l}9.3 \\
(14 \\
\end{array}$ & $\begin{array}{l}10.1 \\
(6)\end{array}$ & $\begin{array}{l}7.1 \\
\text { (3) } \\
\end{array}$ & $\begin{array}{l}5.6 \\
(5) \\
\end{array}$ & $\begin{array}{l}5 . \\
\text { (3. } \\
\end{array}$ & & & $\begin{array}{l}8.0 \\
(4) \\
\end{array}$ & $\begin{array}{l}5.0 \\
\text { (1) }\end{array}$ & - & \begin{tabular}{|l}
6.0 \\
(1) \\
\end{tabular} & $\begin{array}{l}7.0 \\
\text { (3) } \\
\end{array}$ & $\begin{array}{l}5.5 \\
(2) \\
\end{array}$ & - & $\begin{array}{l}5.5 \\
(2) \\
\end{array}$ & - & $\begin{array}{l}1.8 \\
\text { (1) }\end{array}$ & $\begin{array}{l}4.0 \\
\text { (1) } \\
\end{array}$ & $\begin{array}{l}3.8 \\
(8) \\
\end{array}$ \\
\hline & 8 & $\begin{array}{l}11.2 \\
(36)\end{array}$ & $\begin{array}{l}8.5 \\
(26)\end{array}$ & $\begin{array}{l}6.9 \\
(14)\end{array}$ & \begin{tabular}{|l}
6.3 \\
$(7)$ \\
\end{tabular} & $\begin{array}{l}5.4 \\
(10) \\
\end{array}$ & $\begin{array}{l}6.6 \\
(6)\end{array}$ & $\begin{array}{l}6.8 \\
(5) \\
\end{array}$ & $\begin{array}{l}4 . \\
5\end{array}$ & & & - & $\begin{array}{l}6.4 \\
(5)\end{array}$ & $\begin{array}{l}14.0 \\
\text { (1) }\end{array}$ & - & - & - & - & - & - & - & $\begin{array}{l}7.0 \\
\text { (1) }\end{array}$ & $\begin{array}{l}3.9 \\
(4)\end{array}$ \\
\hline & 9 & $\begin{array}{l}11.3 \\
(27) \\
\end{array}$ & $\begin{array}{l}8.6 \\
(16)\end{array}$ & $\begin{array}{l}7.0 \\
(4) \\
\end{array}$ & \begin{tabular}{|l|}
5.2 \\
$(9)$ \\
\end{tabular} & $\begin{array}{l}6.3 \\
(4) \\
\end{array}$ & $\begin{array}{r}9.5 \\
\text { (4) } \\
\end{array}$ & $\begin{array}{l}8.5 \\
\text { (2) } \\
\end{array}$ & $\begin{array}{l}6 . \\
(2 \\
\end{array}$ & - & & - & - & - & - & $\begin{array}{l}5.0 \\
(1) \\
\end{array}$ & $\begin{array}{l}2.0 \\
(1) \\
\end{array}$ & - & $\begin{array}{l}7.5 \\
(2) \\
\end{array}$ & - & - & - & $\begin{array}{l}7.2 \\
(5) \\
\end{array}$ \\
\hline & 10 & $\begin{array}{l}9.6 \\
(29)\end{array}$ & $\begin{array}{l}9.7 \\
\text { (11) }\end{array}$ & $\begin{array}{l}6.6 \\
(8)\end{array}$ & $\begin{array}{l}8.3 \\
(7) \\
\end{array}$ & $\begin{array}{l}9.8 \\
(2) \\
\end{array}$ & $\begin{array}{l}7.0 \\
\text { (1) }\end{array}$ & $\begin{array}{l}8.3 \\
(5) \\
\end{array}$ & $\begin{array}{l}7.4 \\
4 \\
\end{array}$ & - & & $\begin{array}{l}4.0 \\
(2)\end{array}$ & $\begin{array}{l}8.5 \\
(2)\end{array}$ & $\begin{array}{l}5.5 \\
\text { (2) }\end{array}$ & \begin{tabular}{|l}
5.0 \\
$(3)$
\end{tabular} & - & $\begin{array}{l}6.0 \\
\text { (1) }\end{array}$ & - & - & - & $\begin{array}{l}2.0 \\
\text { (1) }\end{array}$ & - & $\begin{array}{l}4.5 \\
(10)\end{array}$ \\
\hline & 11 & $\begin{array}{l}8.7 \\
(30)\end{array}$ & $\begin{array}{l}8.0 \\
(10)\end{array}$ & $\begin{array}{l}7.9 \\
(7)\end{array}$ & $\begin{array}{l}5.7 \\
\text { (6) }\end{array}$ & $\begin{array}{l}4.7 \\
(6)\end{array}$ & $\begin{array}{l}5.6 \\
(5)\end{array}$ & 101 & $\begin{array}{l}5 . \\
\text { (2) }\end{array}$ & & & $\begin{array}{l}4.4 \\
(5)\end{array}$ & $\begin{array}{l}5.0 \\
(2)\end{array}$ & , & - & $\begin{array}{l}3.0 \\
\text { (1) }\end{array}$ & $\begin{array}{l}5.5 \\
\text { (2) }\end{array}$ & - & $\begin{array}{l}3.0 \\
\text { (2) }\end{array}$ & - & 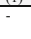 & - & $\begin{array}{l}5.2 \\
(6)\end{array}$ \\
\hline & 12 & $\begin{array}{l}8.3 \\
(19) \\
\end{array}$ & $\begin{array}{l}12.9 \\
(5) \\
\end{array}$ & $\begin{array}{l}7.0 \\
(8) \\
\end{array}$ & $\begin{array}{l}8.6 \\
(7) \\
\end{array}$ & $\begin{array}{l}6.5 \\
(2) \\
\end{array}$ & $\begin{array}{r}9.0 \\
\text { (3) } \\
\end{array}$ & $\begin{array}{l}7.5 \\
\text { (2) } \\
\end{array}$ & $\begin{array}{r}7 . \\
66 \\
\end{array}$ & & & $\begin{array}{l}4.5 \\
\text { (2) } \\
\end{array}$ & - & \begin{tabular}{|l}
3.0 \\
(2)
\end{tabular} & - & $\begin{array}{l}9.0 \\
(1) \\
\end{array}$ & - & - & - & $\begin{array}{l}6.0 \\
\text { (1) } \\
\end{array}$ & $\begin{array}{l}1.0 \\
\text { (1) }\end{array}$ & - & $\begin{array}{r}3.7 \\
(4) \\
\end{array}$ \\
\hline & 13 & $\begin{array}{l}8.0 \\
(21)\end{array}$ & $\begin{array}{l}8.0 \\
(10)\end{array}$ & $\begin{array}{l}8.4 \\
(8)\end{array}$ & $\begin{array}{l}10.9 \\
(4) \\
\end{array}$ & $\begin{array}{l}9.0 \\
(2) \\
\end{array}$ & $\begin{array}{l}5.3 \\
\text { (3) } \\
\end{array}$ & $\begin{array}{l}4.0 \\
\text { (1) } \\
\end{array}$ & $\begin{array}{l}4 . \\
3\end{array}$ & & & $\begin{array}{l}5.0 \\
\text { (1) }\end{array}$ & $\begin{array}{l}7.1 \\
(2)\end{array}$ & $\begin{array}{l}7.0 \\
\text { (1) }\end{array}$ & - & $\begin{array}{l}9.0 \\
\text { (1) }\end{array}$ & - & $\begin{array}{l}8.0 \\
\text { (1) }\end{array}$ & - & - & - & $\begin{array}{l}4.0 \\
\text { (1) }\end{array}$ & $\begin{array}{l}5.0 \\
\text { (3) }\end{array}$ \\
\hline & 14 & $\begin{array}{l}9.6 \\
(19)\end{array}$ & $\begin{array}{l}9.4 \\
(12)\end{array}$ & $\begin{array}{l}7.0 \\
(7)\end{array}$ & \begin{tabular}{|l|}
6.2 \\
$(5)$ \\
\end{tabular} & $\begin{array}{l}7.3 \\
(4) \\
\end{array}$ & $\begin{array}{l}6.3 \\
\text { (3) } \\
\end{array}$ & $\begin{array}{l}6.0 \\
(2) \\
\end{array}$ & $\begin{array}{l}10 \\
12\end{array}$ & & & $\begin{array}{l}7.0 \\
(2)\end{array}$ & $\begin{array}{l}4.5 \\
(2)\end{array}$ & $\begin{array}{l}3.0 \\
\text { (1) }\end{array}$ & \begin{tabular}{|l}
5.5 \\
(2) \\
\end{tabular} & - & - & $\begin{array}{l}4.8 \\
\text { (1) }\end{array}$ & $\begin{array}{l}5.0 \\
\text { (1) }\end{array}$ & - & - & - & $\begin{array}{l}11.5 \\
\text { (2) }\end{array}$ \\
\hline & 15 & $\begin{array}{l}6.2 \\
\text { (11) }\end{array}$ & $\begin{array}{l}5.7 \\
(10)\end{array}$ & $\begin{array}{l}5.9 \\
(5)\end{array}$ & $\begin{array}{l}7.3 \\
(6)\end{array}$ & $\begin{array}{l}6.0 \\
\text { (1) }\end{array}$ & $\begin{array}{l}5.0 \\
\text { (2) }\end{array}$ & - & $\begin{array}{l}10 \\
(2\end{array}$ & & & $\begin{array}{l}3.0 \\
\text { (1) }\end{array}$ & - & - & - & $\begin{array}{l}5.0 \\
\text { (1) }\end{array}$ & - & - & $\begin{array}{l}2.0 \\
\text { (1) }\end{array}$ & $\begin{array}{l}5.0 \\
\text { (1) }\end{array}$ & - & $\begin{array}{l}8.0 \\
\text { (1) }\end{array}$ & $\begin{array}{l}4.0 \\
(6)\end{array}$ \\
\hline & 16 & $\begin{array}{l}8.3 \\
(13)\end{array}$ & $\begin{array}{l}8.0 \\
(8)\end{array}$ & $\begin{array}{l}6.0 \\
(5)\end{array}$ & \begin{tabular}{|l}
7.1 \\
$(3)$ \\
\end{tabular} & $\begin{array}{l}5.5 \\
(2) \\
\end{array}$ & - & $\begin{array}{l}4.0 \\
\text { (1) } \\
\end{array}$ & - & - & & - & $\begin{array}{l}4.1 \\
(3)\end{array}$ & $\begin{array}{l}2.0 \\
\text { (1) }\end{array}$ & \begin{tabular}{|l|}
6.0 \\
$(1)$
\end{tabular} & $\begin{array}{l}8.0 \\
\text { (1) } \\
\end{array}$ & - & - & - & $\begin{array}{l}4.0 \\
\text { (1) }\end{array}$ & $\begin{array}{l}3.0 \\
\text { (1) } \\
\end{array}$ & $\begin{array}{l}2.0 \\
\text { (1) }\end{array}$ & $\begin{array}{l}6.0 \\
(1)\end{array}$ \\
\hline & 17 & $\begin{array}{l}11.4 \\
(13) \\
\end{array}$ & $\begin{array}{l}12.4 \\
(4) \\
\end{array}$ & $\begin{array}{l}8.2 \\
(5) \\
\end{array}$ & \begin{tabular}{|l}
5.7 \\
$(3)$ \\
\end{tabular} & $\begin{array}{l}5.0 \\
(1) \\
\end{array}$ & $\begin{array}{l}6.5 \\
(2) \\
\end{array}$ & $\begin{array}{l}5.8 \\
\text { (4) } \\
\end{array}$ & 6. & & & $\begin{array}{l}5.0 \\
\text { (1) }\end{array}$ & 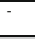 & - & - & - & - & - & \begin{tabular}{|l|}
3.0 \\
$(1)$ \\
\end{tabular} & - & - & - & $\begin{array}{l}3.5 \\
(2) \\
\end{array}$ \\
\hline & 18 & $\begin{array}{l}7.6 \\
\text { (14) } \\
\end{array}$ & $\begin{array}{l}7.0 \\
(2) \\
\end{array}$ & $\begin{array}{l}6.5 \\
(4) \\
\end{array}$ & \begin{tabular}{|l|}
7.0 \\
$(1)$ \\
\end{tabular} & $\begin{array}{l}4.5 \\
(2) \\
\end{array}$ & $\begin{array}{l}8.2 \\
\text { (3) } \\
\end{array}$ & $\begin{array}{l}4.5 \\
\text { (1) } \\
\end{array}$ & $\begin{array}{l}6 . \\
(1 \\
\end{array}$ & 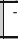 & & - & $\begin{array}{l}5.3 \\
(3) \\
\end{array}$ & \begin{tabular}{|l|}
5.5 \\
$(2)$ \\
\end{tabular} & - & - & - & $\begin{array}{l}4.0 \\
\text { (1) }\end{array}$ & - & $\begin{array}{l}4.0 \\
\text { (1) }\end{array}$ & - & - & $\begin{array}{l}4.4 \\
(7)\end{array}$ \\
\hline & 19 & $\begin{array}{l}7.0 \\
(6)\end{array}$ & $\begin{array}{l}6.0 \\
(3) \\
\end{array}$ & $\begin{array}{l}10.0 \\
(4) \\
\end{array}$ & $\begin{array}{l}5.5 \\
(2) \\
\end{array}$ & $\begin{array}{l}6.5 \\
(2) \\
\end{array}$ & $\begin{array}{l}5.0 \\
(2) \\
\end{array}$ & $\begin{array}{l}6.0 \\
(2) \\
\end{array}$ & $\begin{array}{l}7 . \\
\text { (1) }\end{array}$ & & & $\begin{array}{r}7.5 \\
(2) \\
\end{array}$ & $\begin{array}{l}6.0 \\
(1)\end{array}$ & $\begin{array}{l}5.0 \\
\text { (1) }\end{array}$ & \begin{tabular}{|l}
3.0 \\
(1) \\
\end{tabular} & - & $\begin{array}{l}5.7 \\
\text { (1) } \\
\end{array}$ & - & - & - & - & $\begin{array}{l}4.0 \\
\text { (1) }\end{array}$ & $\begin{array}{l}1.9 \\
(4) \\
\end{array}$ \\
\hline & 20 & $\begin{array}{l}6.2 \\
\text { (9) } \\
\end{array}$ & $\begin{array}{l}6.4 \\
(6) \\
\end{array}$ & $\begin{array}{l}5.0 \\
\text { (1) }\end{array}$ & \begin{tabular}{|l}
9.3 \\
$(3)$ \\
\end{tabular} & $\begin{array}{l}9.0 \\
(1) \\
\end{array}$ & $\begin{array}{l}2.9 \\
\text { (1) } \\
\end{array}$ & $\begin{array}{l}4.0 \\
\text { (1) } \\
\end{array}$ & $\begin{array}{l}7 . \\
(2 \\
\end{array}$ & - & & - & - & $\begin{array}{l}5.2 \\
\text { (1) }\end{array}$ & - & - & $\begin{array}{l}5.0 \\
(1) \\
\end{array}$ & - & - & - & - & - & $\begin{array}{l}3.9 \\
\text { (1) }\end{array}$ \\
\hline & $>20$ & $\begin{array}{l}6.0 \\
(138)\end{array}$ & $\begin{array}{l}4.6 \\
\text { (71) }\end{array}$ & $\begin{array}{l}5.0 \\
(52)\end{array}$ & \begin{tabular}{|l|l}
4.4 \\
$(35$ \\
\end{tabular} & $\begin{array}{l}5.8 \\
(29)\end{array}$ & $\begin{array}{l}3.7 \\
\text { (26) }\end{array}$ & $\begin{array}{l}3.6 \\
(13 \\
\end{array}$ & $\begin{array}{l}3 . \\
0\end{array}$ & & & $\begin{array}{l}4.3 \\
(13)\end{array}$ & $\begin{array}{l}3.0 \\
(13)\end{array}$ & \begin{tabular}{|l}
4.5 \\
$(4)$
\end{tabular} & \begin{tabular}{|l|}
3.1 \\
$(5)$
\end{tabular} & $\begin{array}{l}4.8 \\
(7) \\
\end{array}$ & $\begin{array}{l}3.7 \\
(3)\end{array}$ & $\begin{array}{l}4.9 \\
(7)\end{array}$ & $\begin{array}{l}3.9 \\
(5)\end{array}$ & $\begin{array}{l}.3 \\
\text { (4) }\end{array}$ & $\begin{array}{l}4.7 \\
\text { (3) }\end{array}$ & $\begin{array}{l}2.3 \\
(4)\end{array}$ & $\begin{array}{l}2.2 \\
(60)\end{array}$ \\
\hline
\end{tabular}


provide the average length of the longest intermittency spell in years and-in brackets - the number of offenders whose criminal careers meet the criteria in the row and column applicable to that particular cell. Cells displaying a "_" represent combinations of the number of pre- and post-intermittency convictions not observed in our sample. Given the large number of cells in this cross tabulation, to ease interpretation, cells have been color-coded based on average spell length, with darker colors depicting longer average intermittency. Table 2 for example shows that in our sample, 10 individuals had their longest intermittency spell after 6 convictions and followed by five more convictions. In between, these 10 offenders had an average conviction-free period of 7 years. In line with our above-formulated expectations, the average longest intermittency spell is longest for offenders with a limited number of convictions both pre- and post-intermittency. As either the number of pre- or post-intermittency convictions increases - moving either down from the top left corner of the table or to the right from the top left corner, the average longest intermittency spell decreases. Those individuals offending many times prior to as well as after their intermittency period tend to display the shortest intermittency spells (bottom right corner of the table).

While informative, the averages displayed in Table 2 obscure an important aspect of our data, namely that regardless of the number of both pre- and post-intermittency convictions, there is ample variation in the length of the longest intermittency period. Even among prolific offenders, there are some that experience extended conviction-free intervals. Despite the overall pattern matching expectations, our data also show prolonged periods of intermittency where they were least anticipated. To illustrate, given various minimum numbers of convictions before and after the spell, Fig. 3 shows the distribution of the longest intermittency spell in individuals' criminal careers. Figure 3 e, for example, shows the distribution of the longest intermittency spell for offenders with at least three convictions before the longest spell (pre convictions) and three convictions after the longest spell (post convictions). Given a minimum of three pre and three post convictions, most offenders have longest intermittency spells between 0 and 10 years. Some individuals $(N=47)$ only have convictions in consecutive age years, not displaying intermittency $(0)$ at all on a yearly level. At the top of the distribution, 167 individuals display a gap of five years without convictions in between at least three pre and three post convictions. Only two individuals have a period of over 25 years without convictions, preceded and followed by at least 3 convictions. Although the absolute number of offenders meeting these criteria becomes smaller as the number of pre- and post-intermittency convictions increases, the distribution of intermittency spells remains remarkably similar in terms of both width and skewness.

To further examine the extent to which a lengthy period of intermittency can be regarded as "unexpected" within the offender's criminal career, we apply the backward projection method described in Barnett et al. [2]. To the extent that free and active offenders' convictions occur according to a Poisson stochastic process, the intervals between convictions should on average be equal. That is, for an offender committing five crimes over a 10-year period, the expected interval between subsequent offenses is 2 years. The extent to which the predicted intervals between convictions resemble those actually observed reflects the accuracy of the stochastic model. Stated differently, the extent to which observed intervals differ from those predicted reflects the extent to which these observed intervals can be considered "exceptional." The lines in Fig. 3 visualize the extent to which the duration of longest intermittency spell in an offender's 


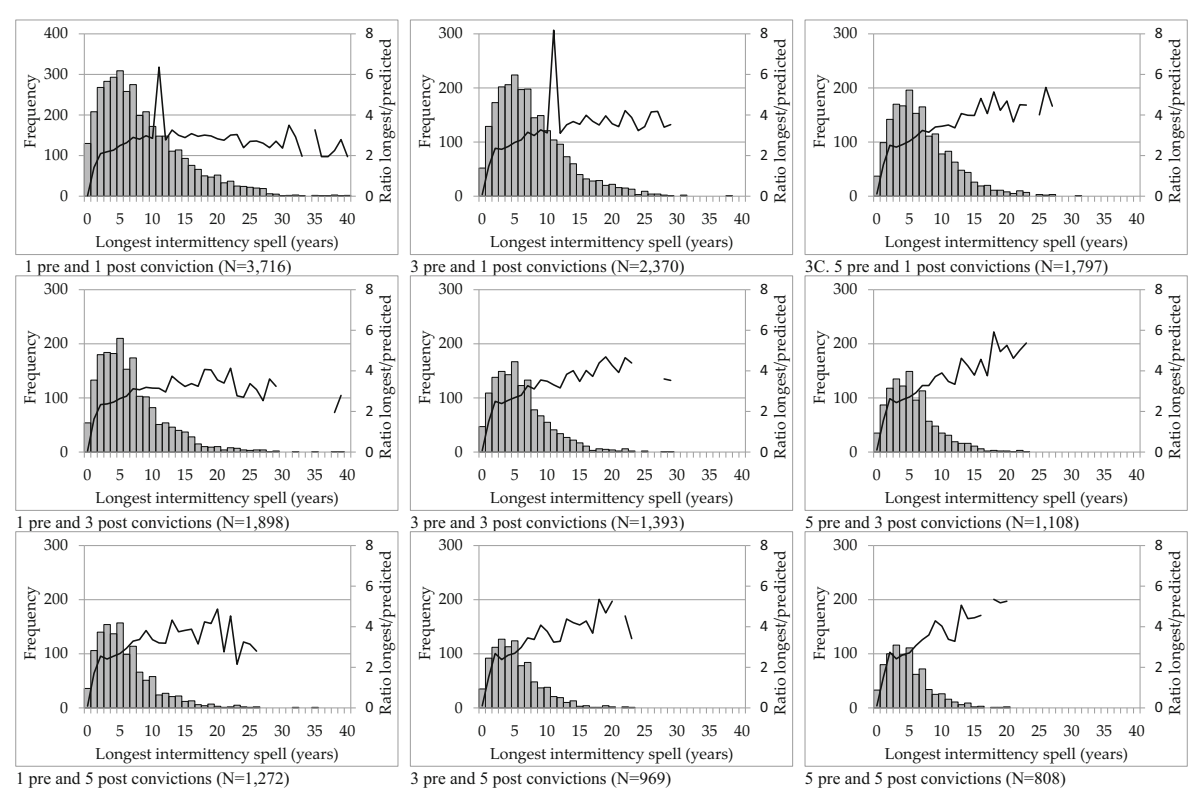

Fig. 3 Distribution longest intermittency spells in career given minimum number of pre and post convictions (Please notice that the scale of the y-axis of Fig. 3 differs from the scale of the other figures. Furthermore, the total number of individuals included in each figure differs as not all individuals commit the specific number of convictions that was used as cut-off point. For example, only those individuals convicted 6 times or more in total ( 3 pre and 3 post convictions) are included in Fig. 3.

active criminal career deviates from the interval duration expected given both the length of the criminally active period and the total number of convictions. For each offender convicted in at least three different years, we determined the total number of years free on the street between the first and last known conviction. Divided by the total number of years with at least one conviction, this yields the predicted interval between conviction years. We then take the ratio of the longest intermittency period for that offender and this predicted interval to gauge the extent to which the longest intermittency period deviates from probabilistic expectations. As becomes clear from Fig. 3, the more active the offender, the more unexpected it is for him or her to experience a prolonged period of intermittency. Active offenders that do experience a prolonged interval between subsequent convictions can be argued to, instead of going through a temporary lull in offending, have terminated one criminal career and then restarted another.

\section{Pre- and Post-Intermittency Offending}

To further explore the question whether pre- and post-intermittency offending are best considered as constituting one or two criminal careers, we examine similarities and differences in offense patterns before and after the longest convictionfree interval in the individual's criminal career. Table 3 presents criminal career characteristics for individuals given different numbers of pre- and post- 
intermittency convictions and different lengths of the minimum conviction-free period. Table 3 provides descriptives for the total criminal career, as well as for pre-intermittency episodes of offending and post-intermittency episodes of offending separately. For example, 1592 offenders (out of 3716 repeat offenders) had a conviction-free period of at least 5 years and committed at least 3 crimes before this period (the pre-intermittency episode of their career) and at least 1 crime after this period (the post-intermittency episode of their career). On average, these offenders started offending at age 19.4, stopped offending at age 31.7 , and restarted committing crimes at age 42.8. During the pre-intermittency episode, they were convicted 11.2 times on average, while during the postintermittency episode, they were convicted 4.7 times on average. They spent more time in prison and were more diverse in their offending prior to their longest conviction-free period. ${ }^{5}$

Overall, Table 3 shows that, as the number of post-intermittency convictions increases, age of criminal career onset and age at both the start and end of the intermittency period go down. With increasing numbers of post-intermittency convictions, the length of the post-intermittency phase increases more steeply than the number of criminal years, evidencing a post-intermittency period that itself is interspersed with conviction-free intervals. As the number of post-intermittency convictions increases, so does the average diversity of offenses. These patterns generally become less pronounced as the number of pre-intermittency convictions goes up. As the minimum intermittency spell increases, the age of onset also increases, indicating - in line with prior research [1] — that especially those starting their criminal careers early tend to show short intermittency spells.

\section{Specialization across Different Intermittency Periods}

In answer to our final research question, we explore patterns of specialization bridging the longest intermittency period for offenders with different numbers of pre- and post-intermittency convictions. In other words we ask: Do individuals simply continue their former behavior after a long (and for some unanticipated) period of non-offending or do they shift their focus to other types of offenses? When offenders shift from committing one or predominantly one type of crime during the first criminal episode to another type of crime after the longest intermittent period, this shift could be taken to consider the post-intermittency period a second criminal career, rather than a continuation of the first. For example, an offender may be a robber first but re-onset offending by committing mostly frauds. As we use transition matrices to assess offense patterns across the

\footnotetext{
${ }^{5}$ Diversity in offending is measured here by means of the diversity index: this is an individual measure of crime type versatility that 'reflects the probability that any two offenses drawn randomly from an individual's particular set of offenses belong to separate offending categories' ([29]:1153). The diversity index is given by$$
D=1-\sum_{m=1}^{M} p_{m}^{2}
$$

where $p$ equals the proportion of offenses and $m=1,2, \ldots, \mathrm{M}$ indicating the offense categories. All crimes are categorized into one of the crime types: (1) violent crime, (2) property crime, (3) drugs and guns, and (4) other crimes. The minimum value of $D$ equals 0 , indicating complete specialization. The maximum value of $D$ when using four offense categories equals 0.75 , indicating complete versatility.
} 


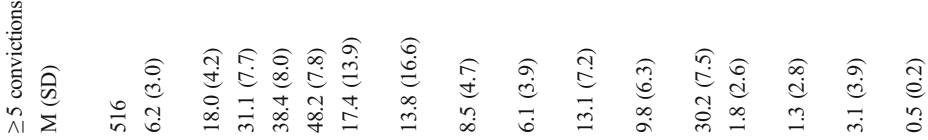

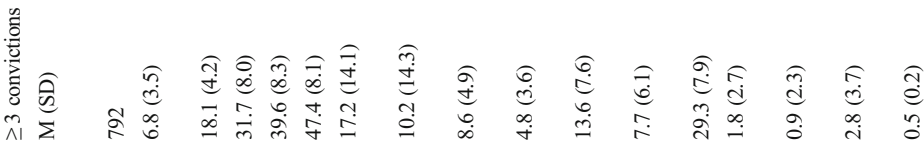

总产劳

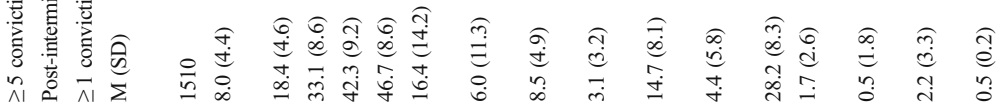

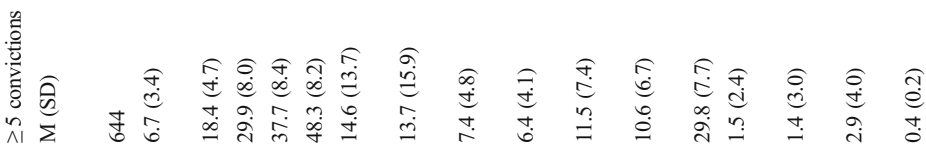

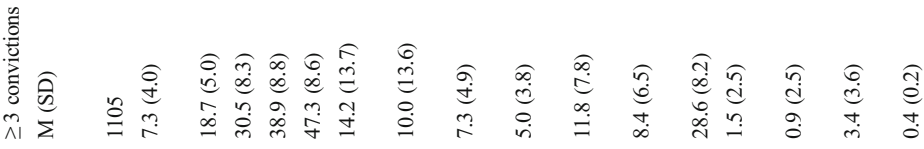

突

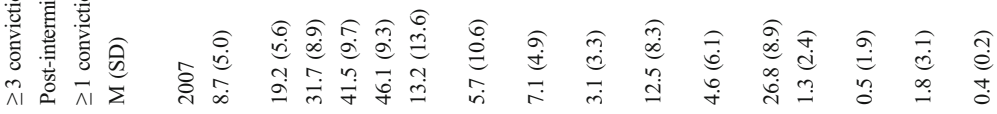

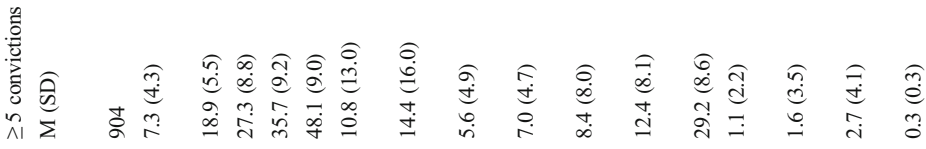

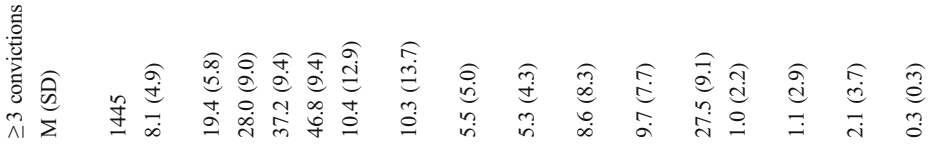

总产产产

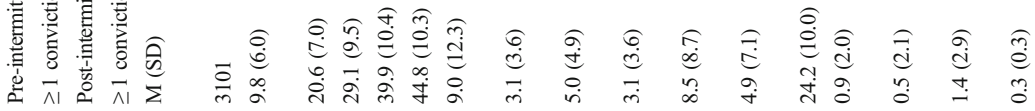

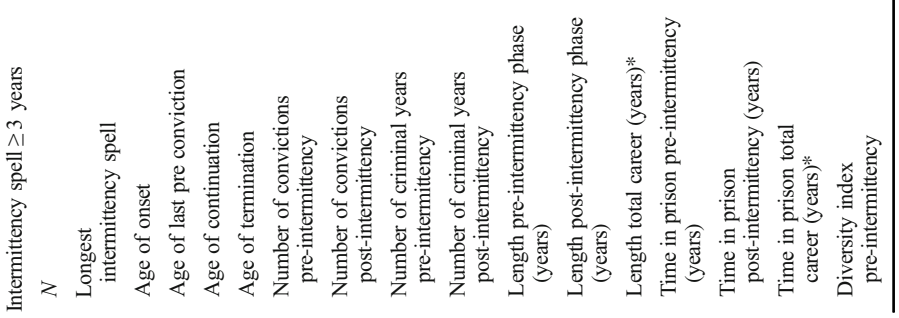




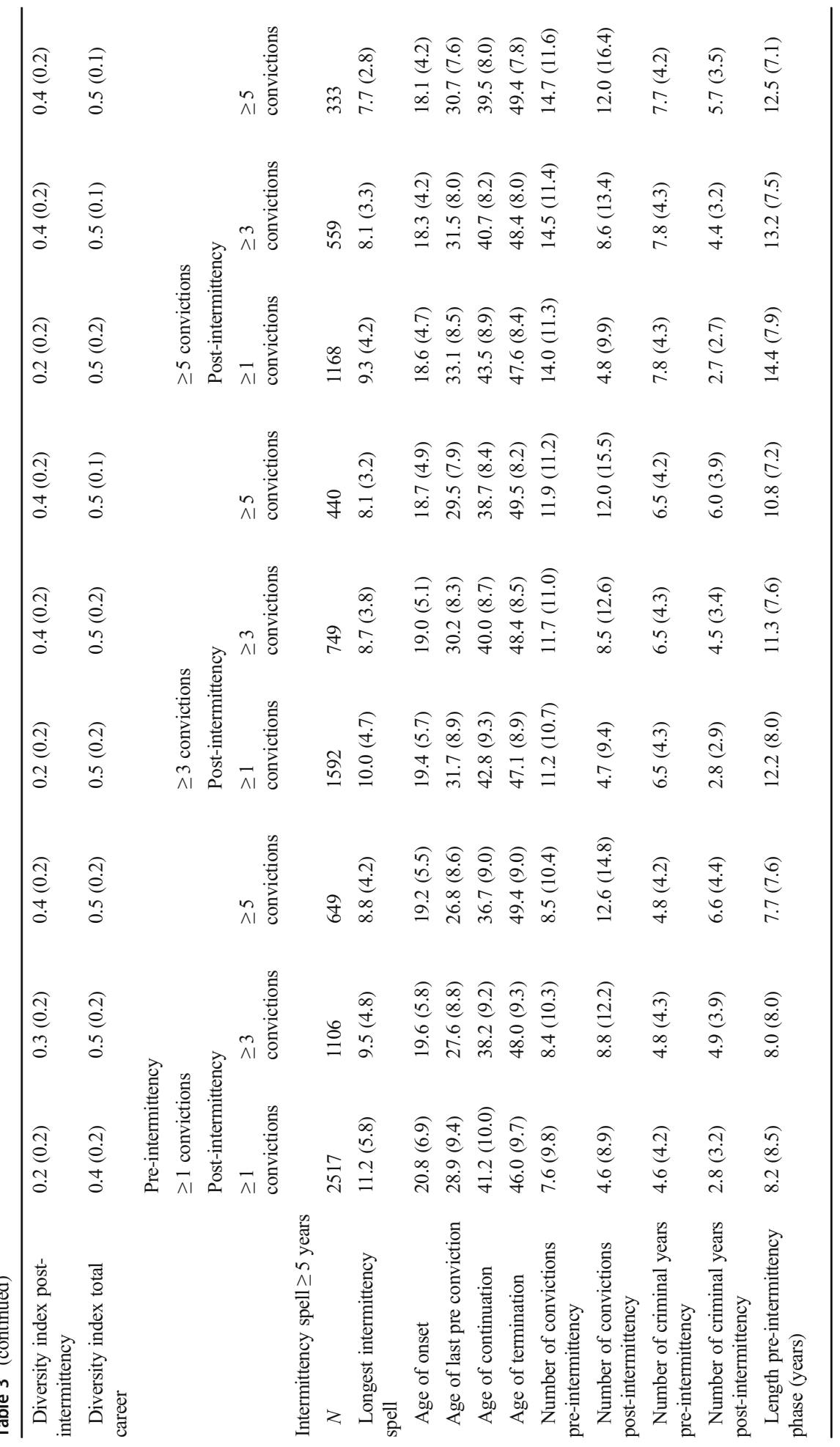




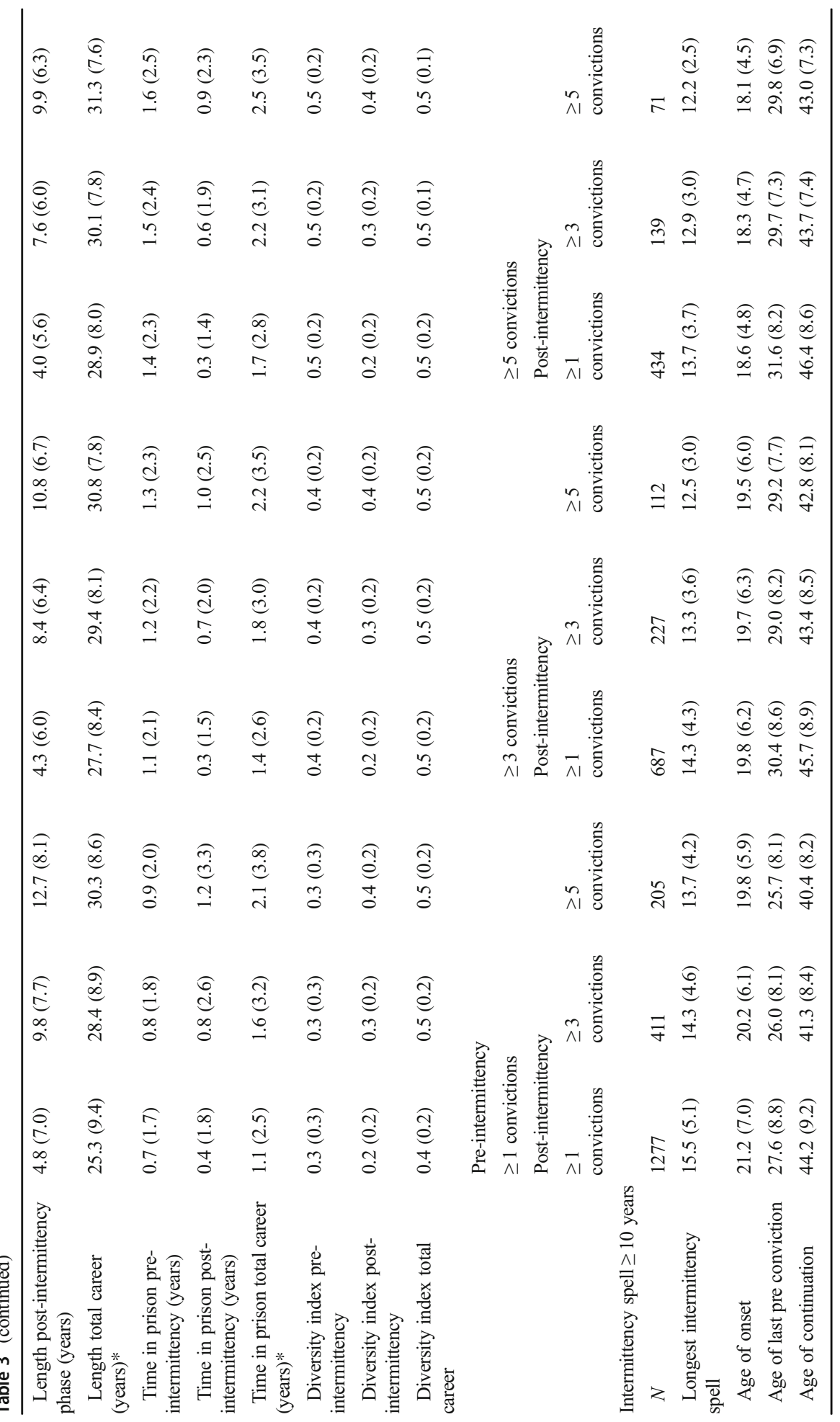




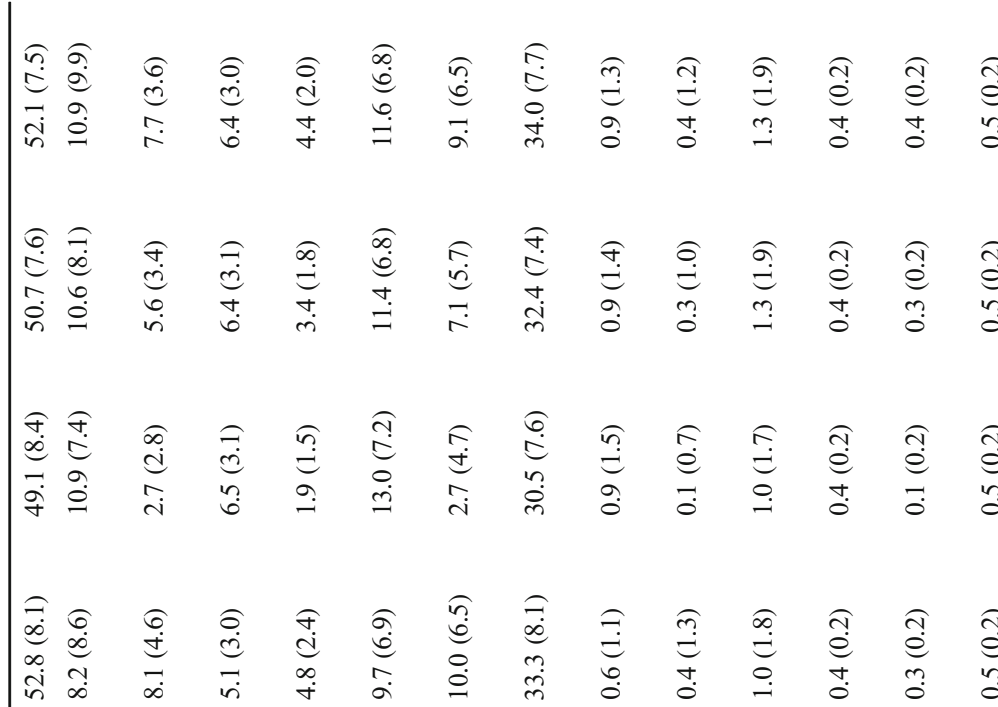

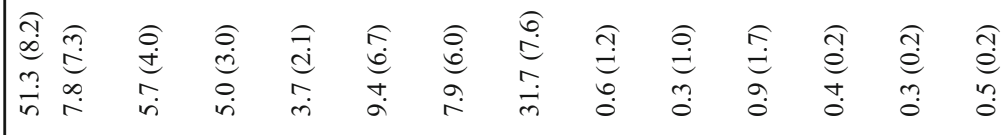

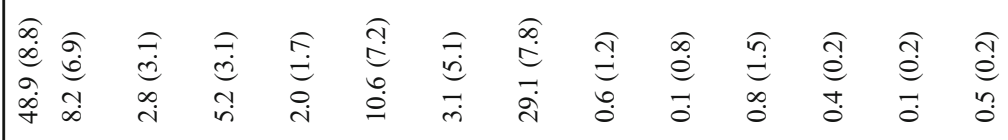

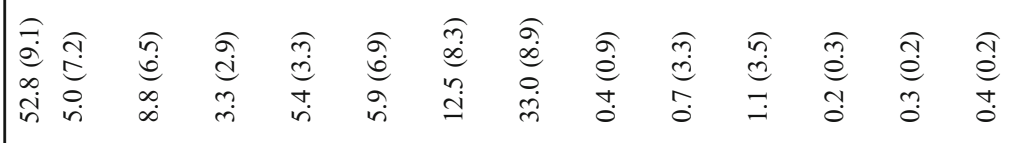

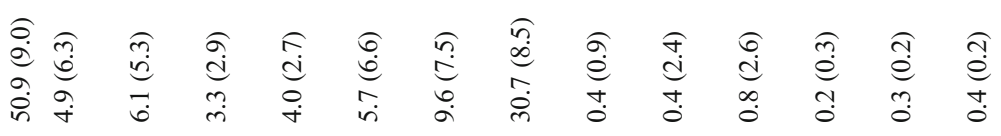

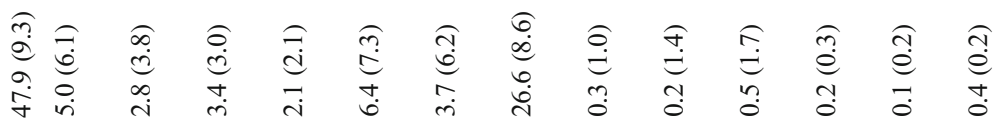

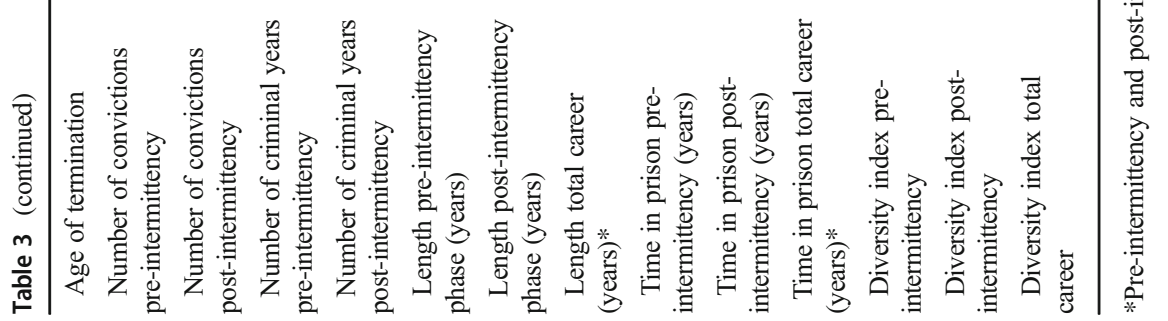


pre- and post-intermittency episodes of the criminal career, the Forward Specialization Coefficient (FSC) is best suited to examine specialization [12]. ${ }^{6}$

An advantage of transition matrices is that they, unlike the diversity index used in Table 3, give insight into the type of crime in which offenders specialize and into transitions between the various types. In this study, specialization across criminal career episodes is determined by assigning individuals to their dominant crime type before and after the longest intermittency spell separately, enabling interpretation of the sequence of offense types. When over half of the convictions during a given period are for the same type of crime, for that particular period the offender is assigned to that particular crime type. When half or less than half of the convictions in a given period are for the same crime type, offenders are referred to as versatile for that particular period. The same four crime types are used as for calculating the diversity index (see footnote 4) only adding the category versatile because of the aggregated nature of the FSC.

Figure 4 provides the FSC for different types of pre-intermittency offending across different combinations of both the number of pre- and post-intermittency convictions and different lengths of the longest intermittency period. Values of the FSC range from 0 to 1 , with higher values indicating increased levels of specialization in offending. To ease interpretation, cells are again color coded, with, for each type of pre-intermittent offending, darker cells showing higher levels of specialization compared to the overall mean level of specialization observed for that offense type. So, for offenders whose preintermittency is characterized as violent (top left corner), who have one preintermittency conviction, and, following an intermittent period of 3 years, only have a single post-intermittency conviction, the FSC has a value of .123 indicating a low level of specialization and thus a high likelihood of the post-intermittent conviction being a non-violent offense. ${ }^{7}$ Unsurprisingly, the comprising "other" category shows the highest overall FCS values, regardless of the length of the longest intermittency period or the number of pre- and post-intermittency convictions. For both property and drugs/guns offending, specialization decreases and is eventually absent as the length of the longest intermittency period increases. This pattern is less clear for violence and other offending. For these types of offending, specialization seems to increase as the number of post-intermittency convictions increases. That is, those offenders whose preintermittency offense period could be characterized as predominantly "other" offending have higher likelihoods of continuing to commit "other" offenses after their longest intermittency period if they have a higher number of post-intermittency convictions. Continuation of a versatile pattern of offending seems most prominent after a lengthy intermittency period. Overall, the findings presented in Fig. 4 seem to indicate that, as the longest intermittency period in the offender's criminal career increases, offenders engaging in either property or drugs/guns offending are least likely to continue committing similar types of offenses, even when the pre-intermittency criminal career

\footnotetext{
${ }^{6}$ The FSC is an aggregate measure calculated for each of the diagonal cells (where row and column indicate the same offense type) in a transition matrix and is given by

$$
F S C_{j k}=\frac{O_{j k}-E_{j k}}{R_{j}-E_{j k}}
$$

with row $j$ and column $k . O_{j k}$ is the observed number of crimes in cell $j k, E_{j k}$ is the expected number of crimes in cell $j k$ by chance, and $R_{j}$ is the row total of row $j$.

7 The FSC can have a negative value, indicating that individuals committing a certain crime type preintermittency have a tendency not to commit that crime type in the post-intermittency period [14].
} 


\begin{tabular}{|c|c|c|c|c|c|c|}
\hline \multirow[t]{2}{*}{ Type of spell } & \multicolumn{6}{|c|}{ Length of the intermittent period } \\
\hline & \multicolumn{3}{|c|}{3} & \multicolumn{3}{|l|}{5} \\
\hline \multirow{3}{*}{ Violence } & .123 & .154 & .111 & .121 & .146 & .084 \\
\hline & .117 & .155 & .046 & .118 & .171 & .075 \\
\hline & .136 & .154 & .040 & .149 & .189 & .061 \\
\hline \multirow{3}{*}{ Property } & .119 & .118 & .118 & .103 & .109 & .105 \\
\hline & .123 & .129 & .120 & .112 & .121 & .104 \\
\hline & .121 & .128 & .134 & .100 & .110 & .113 \\
\hline \multirow{3}{*}{ Drugs/guns } & .045 & .043 & .020 & .019 & .015 & .029 \\
\hline & .041 & .059 & .043 & .027 & .040 & .060 \\
\hline & .040 & .056 & .000 & -.006 & -.002 & .000 \\
\hline \multirow{3}{*}{ Other } & .446 & .453 & .452 & .436 & .440 & .418 \\
\hline & .517 & .525 & .561 & .486 & .477 & .498 \\
\hline & \begin{tabular}{|l}
.586 \\
\end{tabular} & .666 & .730 & .594 & .644 & .715 \\
\hline \multirow{5}{*}{ Versatile } & .008 & .019 & .017 & -.004 & .007 & .011 \\
\hline & .008 & .016 & .012 & -.016 & -.016 & -.018 \\
\hline & .035 & .038 & .027 & .014 & .010 & .002 \\
\hline & 1 & 3 & 5 & 1 & 3 & 5 \\
\hline & \multicolumn{6}{|c|}{ \# of convictions pre-intermittency } \\
\hline
\end{tabular}

\begin{tabular}{|c|c|c|c|c|}
\hline \multicolumn{3}{|l|}{10} & $\begin{array}{l}\text { \# of convictions } \\
\text { post-intermittency }\end{array}$ & Quartiles \\
\hline .098 & .120 & .004 & \multirow{4}{*}{$\begin{array}{l}1 \\
3 \\
5\end{array}$} & \multirow{4}{*}{$\begin{array}{l}<.084 \\
.084-.123 \\
.123-.155 \\
>.155\end{array}$} \\
\hline .135 & .236 & .069 & & \\
\hline \multirow[t]{2}{*}{.195} & .328 & .168 & & \\
\hline & & & & \\
\hline .054 & .055 & .044 & \multirow{4}{*}{$\begin{array}{l}1 \\
3 \\
5\end{array}$} & \multirow{4}{*}{$\begin{array}{l}<.092 \\
.092-.110 \\
.110-.120 \\
>.120\end{array}$} \\
\hline .092 & .120 & .081 & & \\
\hline \multirow[t]{2}{*}{.075} & .098 & .072 & & \\
\hline & & & & \\
\hline-.009 & -.003 & -.002 & \multirow{4}{*}{$\begin{array}{l}1 \\
3 \\
5\end{array}$} & \multirow{4}{*}{$\begin{array}{l}<-.002 \\
-.002-.015 \\
.015-.041 \\
>.041 \\
\end{array}$} \\
\hline-.007 & .000 & .000 & & \\
\hline \multirow[t]{2}{*}{-.010} & .000 & .000 & & \\
\hline & & & & \\
\hline .388 & .440 & .399 & \multirow{4}{*}{$\begin{array}{l}1 \\
3 \\
5\end{array}$} & \multirow{4}{*}{$\begin{array}{l}<.446 \\
.446-.517 \\
.517-.662 \\
>.662\end{array}$} \\
\hline .512 & .532 & .662 & & \\
\hline \multirow[t]{2}{*}{.664} & .786 & .784 & & \\
\hline & & & & \\
\hline .016 & .066 & .091 & 1 & \multirow{5}{*}{$\begin{array}{l}<.008 \\
.008-.016 \\
.016-.063 \\
>.063 \\
\end{array}$} \\
\hline .008 & .063 & .101 & 3 & \\
\hline .090 & .197 & .194 & 5 & \\
\hline & & & & \\
\hline 1 & 3 & 5 & & \\
\hline
\end{tabular}

Fig. 4 Forward specialization coefficient across pre- and post-intermittency offending

consisted of a considerable amount of convictions. Specialization across the longest intermittent period seems to depend much less on either the number of pre- or postintermittent convictions than it does on the length of the longest intermittent period itself.

\section{Discussion}

Of all criminal career parameters, intermittency is arguably the least well documented [38]. Partly, this results from the few available data sets in the criminological field that meet the requirements to convincingly make the distinction between intermittency and termination of offending. Previous studies, as well as results presented here, show that while the mean time period between two offenses is usually short, some offenders do experience prolonged and unanticipated periods of non-offending before reengaging in criminal behavior [2]. For example, the average longest period between two subsequent convictions in an offenders' criminal career was found to be 8.4 years (as part of criminal careers spanning up to three decades), suggesting that any attempt to distinguish termination from temporary abstinence should be based on follow-up periods that span at least a decade and preferably even longer.

While intermittency is usually defined as the time period between two subsequent offenses, the theoretical relevance of the intermittency concept depends heavily on the context of analysis. For one, intermittency could be interpreted as a proxy for the individuals' underlying criminal inclination. Our and others' [1] finding that the average intermittency period decreases as the total number of convictions in the criminal career increases supports such an interpretation. We, however, also found evidence that intermittency can be interpreted as a prelude of the termination of the criminal career. In line with the idea that desistance is best viewed as a process during which various criminal career parameters converge to the eventual total cessation of offending [25], we found that, regardless of the extent of the criminal career, periods of intermittency tend to increase during the final phase of the criminal career. Finally, we found evidence of prolonged periods of intermittency where we least expected them: 
within the midst of very frequent criminal careers. Rather than zig-zagging in and out of crime [24] or temporarily holding up offending [10], we found evidence that previously frequent offenders can experience substantial periods of abstinence of offending before once again frequently engaging in criminal acts. In such cases, where prolonged intermittency is found in the midst of frequent offending, one can rightfully ask whether it is best to speak of revitalizing the original criminal career or whether the postintermittent stint of offending should best be interpreted as a second criminal career independent of the first [2]. While most criminal careers show versatile offending patterns [39], specialization in offending has been found to increase with age [34]. Here, we argued that consistency in offense type across the longest intermittent period could be taken to evidence continuity of a single criminal career, whereas discontinuity in a particular type of offending would signal offenders embarking on a second criminal career. When examining crime types in the pre- and post-intermittency period, we found that for both property and drugs/guns offending, specialization decreased to being eventually absent with increasing periods of intermittency. The lack of continuation in a specific type of crime offenders engage in across the lengthy intermittent periods observed in our data hence seems to support the idea of a second criminal career, rather than a revival of the original criminal career. Subsequent research however is needed to further substantiate such an interpretation.

Despite its many advantages, the major limitation of the present study is its dependence on official data. Interpreting time between convictions as "abstinence of offending" ignores the well-known fact that only a small fraction of all offenses committed eventually result in a conviction. Whereas the length of the actual period being crime-free is likely to be shorter than is represented by the time between convictions, qualitative research supports the notion that offenders do abstain from offending during certain periods in the course of their criminal career [10]. While this does not exclude the possibility that offenders in our sample were simply able to temporarily avoid convictions instead of abstaining from crime, it does bolster an interpretation of intermittent periods beyond mere system effects.

The use of official data also prevents us from ascertaining whether the observed gaps in offending resulted from conscious breaks from offending or rather resulted from unintentional breaks caused by lack of opportunity. While we attempted to address the latter by controlling for time in custody, other factors, like a balking supply or demand of certain illicit goods or a physical disability, could have provoked unintentional crime-free periods. Likewise, the available data do not allow us to differentiate conscious decisions to temporarily "hold out" from offending from failed attempts at desistance.

Finally, though the current data spans a follow-up of nearly 30 years post the 1977 conviction that got individuals in our sample, the observed career lengths and, hence, periods of intermittency, of especially those of younger ages in 1977, may still be underestimated. In fact, for $59.1 \%$ of those aged 12-21 in 1977, their last known conviction was within 10 years until the end of the follow-up - a period across which it is still difficult to distinguish termination from temporary abstinence. Looking at the entire sample, $46.9 \%$ experienced a crime free period of at least 10 years prior to the end of the follow-up, whereas for $61.5 \%$, the last known conviction was more than 5 years prior to the end of the follow-up. These percentages illustrate the challenges studying intermittency pose to the data needed. If anything then, given this limitation to 
our data, periods of intermittency might be found to be even more prevalent and of even longer duration when the offenders in our sample are followed up into increasingly old age.

The current study sought to describe patterns of intermittency within the long-term criminal careers of convicted offenders. Spanning over 40 years of conviction data, we found that observed patterns of intermittency follow theoretical expectations. However, we also found intermittency where it was not expected: amidst frequent - and often versatile - offending. To the extent frequent offending signals stable personal or environmental factors continuously influencing the likelihood of offending, the latter finding does not square with static explanations of criminal development. That is, if not by incarceration, these theories seem to offer little to explain the prolonged absence of offending among these formerly active offenders. Dynamic theories, stressing contextual influences, seem to have more to offer here, as local life circumstances have been found to reduce the likelihood of offending [17, 19], as have longer lasting transitions to adult roles (e.g. [4]). Whether transitions in and out of adult roles coincide with periods of intermittency remains a question to be answered in future studies. Besides several decades of criminal data, such studies also ask for access to long-term patterns in relevant life circumstances, like work, romantic relationships, and parenthood. As noted before, Metcalfe et al. [31] recently shed light on the influence of some of these life events on intermittency, finding that "higher quality bonds of a longer duration are related to even greater time between arrests" (but see also [11]). Especially in the case of high-frequency offenders, examining intermittency on a monthly level (rather than defining intermittency on an annual term, as was done in the present study) might provide interesting insights in lulls of offending in the lives of otherwise highly active offenders.

Given the current emphasis on identity in desistance research, we see a need for future qualitative research on intermittency as well. If desistance requires cognitive transformations and projected images of replacement selves [16] or is triggered by rock-bottom experiences and actualization of feared consequences [36], what does that mean for re-offending after being crime-free for such a long time? Extant qualitative research interprets intermittency partly as "incomplete, unsuccessful, or aborted attempts to quit" offending $[10,11]$, suggesting that while the will to change may have been present, the cognitive transformations needed for lasting behavioral change were not fully realized. Yet, finding intermittency periods of 10 years and over seems to question the general applicability of such an interpretation. Assuming that highly intermittent offenders were indeed able to forge more or less robust conventional replacement selves (but see [24]), the question rather becomes one of adult onset and the circumstances under which adult ex-offenders abandon their conventional identity after so many years.

Open Access This article is licensed under a Creative Commons Attribution 4.0 International License, which permits use, sharing, adaptation, distribution and reproduction in any medium or format, as long as you give appropriate credit to the original author(s) and the source, provide a link to the Creative Commons licence, and indicate if changes were made. The images or other third party material in this article are included in the article's Creative Commons licence, unless indicated otherwise in a credit line to the material. If material is not included in the article's Creative Commons licence and your intended use is not permitted by statutory regulation or exceeds the permitted use, you will need to obtain permission directly from the copyright holder. To view a copy of this licence, visit http://creativecommons.org/licenses/by/4.0/. 


\section{References}

1. Baker, T., Metcalfe, C. F., \& Piquero, A. R. (2015). Measuring the intermittency of criminal careers. Crime \& Delinquency, 61, 1078-1103.

2. Barnett, A., Blumstein, A., \& Farrington, D. P. (1989). A prospective test of a criminal career model. Criminology, 27, 373-388.

3. Blokland, A.A.J. (2005). Crime over the life span; trajectories of criminal behavior in Dutch offenders. Leiden: NCSR.

4. Blokland, A., \& De Schipper, N. (2016). How important are life-course transitions in explaining desistance? Examining the extent to which marriage, divorce and parenthood account for the agecrime relationship in former juvenile delinquents. In J. Shapland, S. Farrall, \& A. Bottoms (Eds.), Global perspectives on desistance; reviewing what we know and looking to the future (pp. 144-160). London: Routledge.

5. Blokland, A. A. J., Nagin, D., \& Nieuwbeerta, P. (2005). Life span offending trajectories of a Dutch conviction cohort. Criminology, 43, 919-954.

6. Blumstein, A., \& Nakamura, K. (2009). Redemption in the presence of widespread criminal background checks. Criminology, 47, 327-359.

7. Blumstein, A., Cohen, J., Roth, J. A., \& Visher, C. A. (1986). Criminal careers and 'career criminals'. Washington: National Academy Press.

8. Bushway, S. D., Thornberry, T. P., \& Krohn, M. D. (2003). Desistance as a developmental process: a comparison of static and dynamic approaches. Journal of Quantitative Criminology, 19, 123-153.

9. Bushway, S. D., Nieuwbeerta, P., \& Blokland, A. (2011). The predictive value of criminal background checks: do age and criminal history affect time to redemption? Criminology, 49, 27-60.

10. Carlsson, C. (2012). Processes of intermittency in criminal careers: notes from a Swedish study on life courses and crime. International Journal of Offender Therapy and Comparative Criminology, 57, 913-938.

11. DeShay, R. A., \& Vieriatis, L. M. (2019). "She's puttin'pressure on me to do somethin": the impact of personal relationships on intermittency in the criminal career. Deviant Behavior (online first). https://doi. org/10.1080/01639625.2019.1594265.

12. Farrington, D. P. (1986). Age and crime. In M. Tonry \& N. Morris (Eds.), Crime and justice: an annual review of research (Vol. 7, pp. 189-250). Chicago: University of Chicago Press.

13. Farrington, D. P. (2005). Introduction to integrated developmental and life-course theories of offending. In D. P. Farrington (Ed.), Integrated developmental and life-course theories of offending (pp. 1-14). New Brunswick: Transaction Publishers.

14. Farrington, D. P., Snyder, H. N., \& Finnegan, T. A. (1988). Specialization in juvenile court careers. Criminology, 26, 461-487.

15. Frazier, C. E. (1976). Theoretical approaches to deviance: an evaluation. Columbus: Merrill.

16. Giordano, P. C., Cernkovich, S. A., \& Rudolph, J. L. (2002). Gender, crime, and desistance: toward a theory of cognitive transformation. American Journal of Sociology, 107(4), 990-1164.

17. Griffin, M. L., \& Armstrong, G. S. (2003). The effect of local life circumstances on female probationers' offending. Justice Quarterly, 20, 213-239.

18. Hodge, A. I. (2018). Correlates of intermittent offending among youth with serious offense histories: personal characteristics, social support, and social roles. Unpublished doctoral dissertation: Ohio State University.

19. Horney, J., Wayne Osgood, D., \& Haen Marshall, I. (1995). Criminal careers in the short-term: intraindividual variability in crime and its relation to local life circumstances. American Sociological Review, 60, 655-673.

20. Kazemian, L. (2007). Desistance from crime: theoretical, empirical, methodological, and policy considerations. Journal of Contemporary Criminal Justice, 23(1), 5-27.

21. Kurlychek, M. C., Brame, R., \& Bushway, S. D. (2006). Scarlet letters and recidivism: does an old criminal record predict future offending? Criminology \& Public Policy, 5, 483-504.

22. Land, K. C., McCall, P., \& Nagin, D. S. (1996). A comparison of Poisson, negative binomial, and semiparametric mixed Poisson regression models with empirical applications to criminal careers data. Sociological Methods \& Research, 24, 387-442.

23. Laub, J. H., \& Sampson, R. J. (2001). Understanding desistance from crime. Crime and Justice, 28, 1-69.

24. Laub, J. H., and Sampson, R. J. (2003). Shared beginnings, divergent lives. Harvard: Harvard University Press.

25. Loeber, R., \& LeBlanc, M. (1990). Toward a developmental criminology. In M. Tonry \& N. Morris (Eds.), Crime and justice: an annual review of research (Vol. 12, pp. 375-473). Chicago: University of Chicago Press.

26. Loeber, R., Hoeve, M., Slot, W. M., \& Van der Laan, P. H. (2012). Persisters and desisters in crime from adolescence into adulthood. Farnham: Ashgate. 
27. Maruna, S. (2001). Making good: how ex-convicts reform and rebuild their lives. Washington: American Psychological Association.

28. Matza, D. (1964). Delinquency and drift. New York: Wiley.

29. Mazerolle, P., Brame, R., Paternoster, R., Piquero, A., \& Dean, C. (2000). Onset age, persistence, and offending versatility: comparisons across gender. Criminology, 38, 1143-1172.

30. Metcalfe, C., \& Baker, T. (2014). The drift from convention to crime. Exploring the relationship between co-offending and intermittency. Criminal Justice and Behavior, 41(1), 75-90.

31. Metcalfe, C., Baker, T., \& Brady, C. M. (2019). Exploring the relationship between lasting, quality social bonds and intermittency in offending. American Journal of Criminal Justice, 44, 892-912. https://doi. org/10.1007/s12103-019-09486-4.

32. Moffitt, T. E. (1993). Adolescence-limited and life-course persistent antisocial behaviour: a developmental taxonomy. Psychological Review, 100, 674-701.

33. Nagin, D. S., \& Land, K. C. (1993). Age, criminal careers, and population heterogeneity: specification and estimation of a nonparametric, mixed Poisson model. Criminology, 31, 327-362.

34. Nieuwbeerta, P., Blokland, A. A. J., Piquero, A. R., \& Sweeten, G. (2011). A life-course analysis of offense specialization across age: introducing a new method for studying individual specialization over the life course. Crime \& Delinquency, 57, 3-28.

35. Ouellet, F. (2019). Stop and go: explaining the timing of intermittency cycles in criminal careers. Crime and Delinquency, 65(5), 630-656.

36. Paternoster, R., \& Bushway, S. D. (2009). Desistance and the feared self: toward an identity theory of desistance. The Journal of Criminal Law and Criminology, 99(4), 1103-1156.

37. Petersilia, J., Greenwood, P. W., \& Lavin, M. (1977). Criminal careers of habitual felons. Santa Monica: RAND.

38. Piquero, A. R. (2004). Somewhere between persistence and desistance: the intermittency of criminal careers. In R. Immarigeon \& S. Maruna (Eds.), After crime and punishment: pathways to offender reintegration (pp. 102-125). Cullompton: Willan Publishing.

39. Piquero, A. R., Farrington, D. P., \& Blumstein, A. (2003). The criminal career paradigm. Crime and Justice, 30, 359-506.

40. Piquero, A. R., Farrington, D. P., \& Blumstein, A. (2007). Key issues in criminal career research: new analyses of the Cambridge Study in Delinquent Development (Cambridge studies in criminology). Cambridge: Cambridge University Press.

41. Raskin, B. S. (1987). The measurement of time intervals between arrests. In M. E. Wolfgang, T. P. Thornberry, \& R. M. Figlio (Eds.), From boy to man, from delinquency to crime (pp. 59-67). Chicago: University of Chicago Press.

42. Sampson, R. J., \& Laub, J. H. (1993). Crime in the making: pathways and turning points through life. Cambridge: Harvard University Press.

43. Van Koppen, M. V., \& De Poot, C. (2013). The truck driver who bought a café: offenders on their involvement mechanisms for organized crime. European Journal of Criminology, 10, 74-88.

Publisher's Note Springer Nature remains neutral with regard to jurisdictional claims in published maps and institutional affiliations.

\title{
Affiliations
}

\section{Vere van Koppen $^{1}$ • Elanie Rodermond ${ }^{1}$ • Arjan Blokland ${ }^{2,3}$}

\author{
Elanie Rodermond \\ e.rodermond@vu.nl \\ Arjan Blokland \\ ablokland@nscr.nl
}

1 VU University Amsterdam, De Boelelaan 1105, 1081 HV Amsterdam, Netherlands

2 Netherlands Institute for the Study of Crime and Law Enforcement (NSCR), Amsterdam, Netherlands

3 Leiden University, Rapenburg 70, 2311 EZ Leiden, Netherlands 